\title{
Morte, vida e destino em Schopenhauer e Freud: os "fins da natureza" na metafísica da vontade e na metapsicologia
}

\author{
Death, life and destiny in Schopenhauer and Freud: the "goals of nature" in \\ the metaphysics of will and in the metapsychology
}

\section{William Mattioli*}

Resumo: Neste artigo, pretendo discutir alguns problemas que emergem da associação, já comum na literatura secundária, entre o último dualismo pulsional freudiano, baseado na oposição entre pulsões de vida e de morte, e as teses schopenhauerianas sobre a vida e a morte derivadas de sua metafísica da vontade. A partir de uma confrontação com as leituras de Marcel Zentner e Stephan Atzert, argumentarei a favor da hipótese de que a diferença mais relevante entre os modelos de Freud e de Schopenhauer não diz respeito à distinção no plano ontológico entre dualismo das pulsões e monismo da vontade, mas sim entre sentido biológico e sentido ético da suposta finalidade associada à morte, como "fim" ou "objetivo" da vida. Minha discussão, portanto, gira em torno de uma distinção quanto ao estatuto teleológico que se pode atribuir à dinâmica da relação entre vida e morte nos dois autores.

Palavras-chave: Vida; Morte; Pulsão; Vontade; Destino; Teleologia

\begin{abstract}
In this paper, I intend to discuss some problems that emerge from the association, already common in secondary literature, between Freud's last drive dualism, based on the opposition between life and death drives, and Schopenhauer's theses about life and death derived from his metaphysics of will. Based on a confrontation with the readings of Marcel Zentner and Stephan Atzert, I will argue in favor of the hypothesis that the most relevant difference between the models of Freud and Schopenhauer does not concern the ontological distinction between dualism of drives and monism of the will, but consists in a differentiation between biological and ethical sense of the supposed purpose associated with death, as the "end" or "goal" of life. My discussion, therefore, revolves around a distinction regarding the teleological status that can be attributed to the dynamics of the relationship between life and death in both authors.
\end{abstract}

Keywords: Life; Death; Drive; Will; Destiny; Teleology

Êthos anthropos daímon (o caráter do homem é seu destino)

Heráclito, fragmento 119

Os sofrimentos - que Édipo suportou - aparecem como quando um pobre homem se queixa de que algo lhe falta.

Filho de Laio, pobre estrangeiro na Grécia!

Vida é morte, e morte também é vida.

Hölderlin, Em anil amoroso...

\footnotetext{
" Professor do Departamento de Filosofia da Universidade Federal do Rio de Janeiro, Rio de Janeiro, RJ. E-mail: william.mattioli@gmail.com ORCID: https://orcid.org/0000-0003-2894-548X
} 
Um dos paralelos que se tornaram mais correntes nos comentários aos clássicos da história do pensamento moderno e contemporâneo é aquele entre Freud e Schopenhauer. É certo que isso não se deu por acaso. Se, por um lado, as afinidades temáticas e a proximidade quanto às respostas que ambos os autores propõem para o problema da constituição do humano e da natureza de sua vida psíquica já dariam, por si só, ensejo à diversidade de estudos comparativos presente na literatura especializada, por outro, as menções explícitas de Freud a Schopenhauer, e a disposição do fundador da psicanálise a reconhecer no filósofo um predecessor de sua teoria do inconsciente e das pulsões justificam ainda mais a atenção dada às correlações conceituais entre ambos ${ }^{1}$.

Uma das passagens mais importantes da obra de Freud em que Schopenhauer é diretamente mencionado diz respeito à elaboração de sua teoria das pulsões de vida e de morte, em Além do princípio do prazer (1920). Trata-se de um texto relativamente curto, mas um tanto quanto labiríntico, que estabelece um diálogo complexo com a física, a biologia, a filosofia, a poesia e a mitologia, permeado de desvios, reviravoltas, tergiversações, e marcado por um forte teor especulativo ${ }^{2}$. Tal como o entendo, as duas hipóteses principais que Freud pretende apresentar nesse texto, ao longo de um sinuoso percurso argumentativo que exige do leitor um fôlego e uma atenção particulares, são: 1) o psiquismo é fundamentalmente regido por duas forças de direção opostas, que visam respectivamente à agregação e à desagregação: as pulsões de vida e de morte; 2) essas forças atuam não apenas no âmbito psíquico, mas também no orgânico e biológico; em última instância, sua manifestação psíquica seria um efeito, um desdobramento ou uma ramificação de sua atividade essencialmente orgânica e biológica, portanto, em certo

\footnotetext{
${ }^{1}$ Para chegar à discussão específica que pretendo elaborar neste artigo, faço inicialmente um percurso geral pelos pontos principais e mais relevantes para minha análise da argumentação que Freud elabora em Além do princípio do prazer (1920) e do ensaio de Schopenhauer citado por ele no referido texto: Especulação transcendente sobre a aparente intencionalidade no destino do indivíduo, presente na coleção tardia de ensaios Parerga e paralipomena (1851). As referências à obra de Freud seguem a paginação da edição alemã das obras completas (Sigm. Freud Gesammelte Werke, Band XIII). As traduções são de Paulo César de Souza, com eventuais alterações de nossa parte. Dessas alterações, a mais frequente é a substituição do termo “instinto” (opção que Paulo César adota para traduzir Trieb), por “impulso” ou "pulsão” (uso os dois termos como sinônimos). As referências à obra de Schopenhauer seguem a paginação da edição alemã das obras completas organizada por Paul Deussen. As traduções do ensaio Especulação transcendente sobre a aparente intencionalidade no destino do indivíduo, presente no primeiro volume dos Parerga, são de minha autoria. As traduções dos dois tomos de $O$ mundo como vontade e representação são de Jair Barboza, com eventuais alterações. As traduções do conjunto de ensaios Sobre a ética, presentes no segundo volume dos Parerga, são de Flamarion C. Ramos, também com eventuais alterações.

${ }^{2}$ Cf. MONZANI, Freud. O movimento de um pensamento, 142, 147.
} 
${ }^{3}$ Entendo por 'pré-psíquica' aquela dimensão que antecede o mental do ponto de vista de sua determinação biológica e, nesse sentido, não possui ainda a forma da intencionalidade que lhe confere seu traço específico: seu direcionamento a um objeto. O leitor me perdoará a ausência, aqui, de uma discussão mais aprofundada acerca da relação entre o orgânico e o psíquico e, mais ainda, sobre as possíveis relações entre Freud e Schopenhauer no tocante a esse ponto (agradeço à(o) parecerista anônima(o) que sugeriu esta questão). Se essa ausência não pode ser inteiramente sanada no espaço deste artigo, ela talvez possa ser ao menos minimizada pelas seguintes considerações. Seguindo a interpretação de Gardner (GARDNER, Schopenhauer, Will, and the Unconscious, 381), entendo que, se a vontade schopenhaueriana, em sua essência própria, é caracterizada pelo filósofo como sendo destituída de qualquer componente intencional ou representacional (uma tese que torna problemáticas várias afirmações do filósofo sobre a vontade e seu aspecto finalista), o inconsciente freudiano, pelo contrário, na medida em que se define como instância mental, é marcado por intencionalidade - e é essa intencionalidade que o qualifica como complexo de estados motivacionais. Quando falamos da pulsão como elemento constitutivo do inconsciente, precisamos ter em vista seu direcionamento a um objeto, sua relação com as representações que lhe concedem um conteúdo qualitativo. O direcionamento intencional do conteúdo do inconsciente, por mais primitivo ou distante daquele dos desejos conscientes, é o que o distingue de estados puramente somáticos. Esse me parece ser um aspecto fundamental, por exemplo, da argumentação de Freud no texto $O$ inconsciente (1915). Mesmo que o autor busque ainda caracterizar o inconsciente em termos "econômicos", a partir de um vocabulário quantitativo, isso em nada muda na compreensão de sua intencionalidade, pois, de fato, todo tipo de fenômeno psicológico pode, a partir dessa abordagem, ser caracterizado nos termos de uma "energia psíquica" quantitativamente analisável. Tudo parece indicar, nesse contexto, que o modo como Freud apresenta seu modelo metapsicológico pressupõe uma escolha de princípio pelo vocabulário intencional em detrimento do vocabulário energético / quantitativo. O artigo sobre o inconsciente, como mencionado, talvez seja um dos melhores exemplos disso. A escolha por esse vocabulário mentalista é o que, em última instância, traz inteligibilidade aos fenômenos abordados, razão pela qual ele assume prioridade explicativa. Com efeito, uma das razões essenciais que conduziram Freud à asserção da existência do inconsciente é o fato de que os dados da consciência se mostram profundamente lacunares, de modo que frequentemente nos deparamos com "atos psíquicos que pressupõem, para sua explicação, outros atos de que a consciência não dá testemunho" (Das Unbewusste, 265). Notemos que, nesse argumento, a inteligibilidade daqueles outros atos psíquicos aos quais Freud se refere e dos quais a consciência não dá testemunho só pode estar assegurada se formos capazes de remetê-los cognitivamente a associações psíquicas que nos são de certo modo palpáveis, isto é, a mecanismos intencionais compreensíveis a partir da perspectiva de primeira pessoa, mesmo que estes nos pareçam à primeira vista inteiramente idiossincráticos. A pulsão de morte, por sua vez, parece transcender essa forma de intencionalidade característica do inconsciente enquanto instância psíquica. Por mais que possua ainda uma "finalidade", essa finalidade dificilmente se deixa traduzir nos termos da intencionalidade mental (mesmo inconsciente). Como veremos adiante, há algo da ordem de uma negatividade radical, associada ao esvaziamento inerente à morte, que é refratário à possibilidade de inscrição no aparelho psíquico (cf. MONZANI, Freud. O movimento de um pensamento, 213s. e a literatura ali indicada). Nesse sentido, como argumenta Monzani, a pulsão de morte se revelaria como um elemento fundamental que escapa tanto à consciência quanto ao inconsciente. Desses dois sistemas, apreendemos apenas "os efeitos daquela raiz, efeitos de uma finalidade arcaica e cega, uma espécie de força bruta e mecânica que se instila através de seus derivados.” (Ibid.) Com isso, tal como vejo, a pulsão de morte estaria muito mais próxima da vontade de Schopenhauer do que as caracterizações das pulsões fornecidas por Freud anteriormente e associadas por ele explicitamente ao conceito schopenhaueriano (cf. por exemplo Eine 
A maior dificuldade com a qual Freud se confronta consiste em justificar, tanto empírica quanto conceitualmente, a assunção deste princípio pulsional sui generis denominado por ele de pulsão de morte. Para tanto, ele parte de um fenômeno observável em vários âmbitos da experiência: da clínica psicanalítica à embriologia animal, passando pela análise dos sonhos, do jogo infantil e do comportamento migratório de algumas espécies. Este fenômeno, de importância incontestável para o autor, é o fenômeno da repetição. A instanciação propriamente psicanalítica desse fenômeno será conceitualmente operacionalizada mediante a noção de "compulsão à repetição" . Interessa ao psicanalista, acima de tudo, compreender porque indivíduos que passaram por vivências traumáticas tendem a reatualizar e a reviver essas experiências, seja no sonho, seja em algum comportamento neurótico (que pode ser traduzido na neurose de transferência na clínica). Uma vez que essas vivências foram profundamente desprazerosas, e sua repetição é sempre igualmente acompanhada de desprazer, a tendência do indivíduo a reatualizá-las e repeti-las, simbólica e fantasticamente, passa a ser vista como um problema para a tese geral, sustentada até então por Freud, segundo a qual a dinâmica do aparelho psíquico seria primariamente orientada pelo princípio do prazer.

Falamos aqui numa tendência do indivíduo a reviver as experiências traumáticas pela repetição, mas o fato é que há casos em que essa repetição de experiências desprazerosas parece ocorrer sem o concurso do próprio indivíduo e, mais ainda, sem que o indivíduo tenha sofrido no passado um trauma tipicamente produtor das neuroses traumáticas (como acidentes ou a experiência da guerra, por exemplo). Nesses casos, o indivíduo (o não-neurótico) parece figurar como sujeito passivo submetido às forças do destino, que o colocam sempre numa mesma situação de sofrimento. Em relação a essas pessoas, diz-nos Freud: “dá-se a impressão de um destino que as persegue, de um traço demoníaco (dämonisch) em seu viver”. Veremos, na sequência, o quão próxima está essa ideia de um "destino demoníaco"6 com relação às reflexões de Schopenhauer sobre o destino dos indivíduos, presentes no texto Especulação transcendente sobre a aparente intencionalidade no destino do indivíduo. Este é justamente o texto do qual Freud extrai a citação reproduzida nas páginas finais de Além do princípio do prazer, nas quais vemos o

Schwierigkeit der Psychoanalyse, 12). Ainda segundo Monzani: "essa linha de interpretação nos levaria a acreditar que a pulsão de morte, de fato, não pertenceria à vida psíquica, isto é, que ela é representada no inconsciente, mas que estaria, portanto, além do psíquico e apenas produziria efeitos nessa esfera.” (MONZANI, Freud. O movimento de um pensamento, 214)

${ }^{4}$ Para uma discussão mais detida e filosoficamente orientada sobre a noção de compulsão à repetição, cf. ALMEIDA, Nietzsche e Freud: eterno retorno e compulsão à repetição.

${ }^{5}$ FREUD, Jenseits des Lustprinzips, 20.

"Vale notar, desde já, que o adjetivo “demoníaco" é usado aqui a partir do campo semântico do daimon grego, que designa uma força ou um poder superior e desconhecido, e não tem qualquer referência direta ao sentido cristão de "diabólico”, como observa Paulo César de Souza em nota à sua tradução. 
psicanalista admitir que adentrou inadvertidamente "o porto da filosofia de Schopenhauer, para quem a morte é 'o autêntico resultado' e, portanto, o objetivo da vida, enquanto o

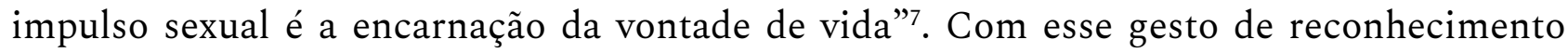
(suficientemente equívoco para que o consideremos cum grano salis), Freud sugere que Schopenhauer teria antecipado não apenas sua tese sobre a pulsão de morte, mas o próprio dualismo entre pulsões de vida e de morte ${ }^{8}$. Mas antes de nos debruçarmos sobre o tema do destino e sobre a apropriação que Freud faz da passagem citada de Schopenhauer, retornemos rapidamente à questão da compulsão à repetição, que é a hipótese que dá origem à noção de pulsão de morte.

Após apresentar uma série de exemplos extraídos da vida de diversos indivíduos e de personagens da literatura, à luz dos quais Freud busca ilustrar aquela ideia de um aparente "destino demoníaco" que guiaria seus cursos de vida, ele diz sentir-se encorajado "a supor que na vida psíquica há realmente uma compulsão à repetição, que sobrepuja o princípio do prazer" . Na conclusão deste capítulo (trata-se do capítulo III), ele se coloca então as questões decisivas que passarão a orientar sua argumentação em direção a um modelo de explicação fortemente especulativo, no qual o princípio do prazer deixa de ser o princípio originário de determinação da dinâmica da vida psíquica:

O que ainda resta é bastante para justificar a hipótese da compulsão à repetição, e esta quer nos parecer mais primordial, mais elementar, mais pulsional do que o princípio do prazer, por ela posto de lado. Se houver na psique uma tal compulsão à repetição, porém, então gostaríamos de saber algo sobre ela, a qual função corresponde, em que condições pode evidenciar-se, e que relação tem com o princípio do prazer, ao qual até agora, afinal, confiamos o domínio sobre o curso dos processos de excitação na vida mental ${ }^{10}$.

O capítulo IV, que se segue a essa passagem, busca fornecer as primeiras pistas para a elaboração de uma resposta às questões ali colocadas, em especial: como se relaciona o princípio do prazer àquela compulsão à repetição, reconhecida como mais primitiva que o primeiro? Para adiantar a resposta, permito-me aqui um rápido salto ao último capítulo. Ali, encontramos a seguinte formulação: o princípio do prazer é uma tendência que está a

\footnotetext{
${ }^{7}$ FREUD, Jenseits des Lustprinzips, 53.

${ }^{8}$ Cf. ZENTNER, “Das Ziel alles Lebens ist der Tod”. Schopenhauer und Freuds Todestrieb, 320 e 322.

${ }^{9}$ FREUD, Jenseits des Lustprinzips, 21.

${ }^{10}$ FREUD, Jenseits des Lustprinzips, 22. Essa reconstrução sintética do argumento freudiano está longe de fazer jus às sutilezas do texto, sobretudo porque desconsidera a função dialética das diversas explicações alternativas apresentadas por ele para o fenômeno da repetição e as reviravoltas argumentativas, em que muitas dessas explicações alternativas vão sendo colocadas de lado no percurso da apresentação. Para uma análise detida e minuciosa dos passos do argumento, cf. MONZANI, Freud. O movimento de um pensamento, 150-226.
} 
serviço de uma função determinada originalmente pelas pulsões por trás da compulsão à repetição, qual seja, a função de "tornar o aparelho psíquico isento de excitação, ou conservar o montante de excitação dentro dele constante ou o menor possível" 11 .

Para chegar a essa conclusão, Freud elabora, ainda no capítulo IV, uma hipótese sobre a gênese das estruturas orgânicas de defesa contra estímulos, naquilo que sua imaginação científica (ao modo de um experimento de pensamento) concebe ter sido um tipo de 'organismo primitivo'. Segundo tal hipótese, esse suposto organismo primitivo (caracterizado como uma “indiferenciada vesícula de substância excitável”)" teria desenvolvido uma membrana protetora contra os choques de excitação provindos do exterior, uma espécie de "para-excitações"13. Esse invólucro, dotado da capacidade de reter estímulos, impede que o organismo seja liquidado pela ação das fortes energias excitatórias provindas do mundo externo, no qual ele se encontra. Através dessa membrana protetora, as energias do mundo exterior penetram "com uma fração de sua intensidade nas camadas adjacentes" 14 .

A partir dessa hipótese, Freud se esforça por esboçar uma teoria filogenética, essencialmente funcionalista, sobre a gênese e o desenvolvimento da consciência. $O$ ponto principal para o escopo de nossa análise diz respeito à função protetora da consciência, na medida em que ela deve preservar a estabilidade da energia interna ao aparelho psíquico, mantendo a dinâmica própria dessa energia em seus processos de transformação e impedindo a deflagração de um processo de nivelamento a partir do exterior, sob o influxo das imensas energias que operam do lado de fora, e cujo efeito levaria à destruição do organismo. Em outras palavras: a consciência mantém a homeostase da energia interna ao aparelho psíquico contra a influência entrópica da energia externa. Nesse sentido, essa estrutura de proteção evita a ocorrência de um processo de inundação e descarga total, que esvaziaria o organismo de toda energia pulsional, levando-o à morte ${ }^{15}$.

\footnotetext{
${ }^{11}$ FREUD, Jenseits des Lustprinzips, 68 (grifo nosso).

${ }^{12}$ FREUD, Jenseits des Lustprinzips, 25.

${ }^{13}$ Cf. MONZANI, Freud. O movimento de um pensamento, 154; e ALMEIDA, Nietzsche e Freud: eterno retorno e compulsão à repetição, 72 .

${ }^{14}$ FREUD, Jenseits des Lustprinzips, 27.

15 O uso intercambiado dos termos "aparelho psíquico" e "organismo" é aqui intencional, e busca refletir a suposição freudiana de que os mecanismos de estabilização, transformação e escoamento de energia é o mesmo em ambos os domínios. Isso está de acordo com a hipótese, mencionada anteriormente, de que as forças que agem no desenvolvimento e na regulação do aparelho psiquismo são as mesmas que agem no desenvolvimento e na regulação do organismo biológico (o que afasta Freud, ao menos nesse momento, de qualquer forma de dualismo de matriz cartesiana). Cf. sobre isso SORIA, Schopenhauer em Além do princípio do prazer: reflexões sobre a relação entre metafísica e metapsicologia, 248. Soria argumenta que as considerações de Freud sobre a história da gênese do aparelho psíquico se fundem com a história da gênese do organismo, "desde sua formação como vesícula indiferenciada até sua constituição como corpo pluricelular com um sistema nervoso central. [...] Ao fundir a reflexão sobre as pulsões no psiquismo com a gênese do organismo vivo, abre-se a via de passagem para se chegar às duas grandes forças que regem os
} 
Dentro desse contexto, a repetição é compreendida como um mecanismo que auxilia na "ligação" das moções pulsionais que chegam ao aparelho psíquico, desencadeadas por um processo de excitação. É essa ligação da energia, à qual Freud dá o nome de "catexia” ou “investimento" (Besetzung), que permite que a energia excitatória seja gerenciada, canalizada e eliminada. Mas é importante notar, aqui, que a fonte das excitações que chegam ao aparelho psíquico não é apenas o mundo externo; elas provêm também do interior do próprio organismo. Nesse caso, contudo, não há uma proteção direta contra elas, e as excitações se propagam sem o atenuante daquela estrutura de 'para-choque', como uma onda interna de sensações de prazer e desprazer ${ }^{16}$.

Freud avança então em direção à conclusão de que a atividade de ligação é originária com relação ao princípio do prazer; o princípio do prazer só pode entrar em ação após o sistema ter "acolhido" a energia que irrompe de alguma fonte de excitação (externa ou interna). Por sua vez, um sistema pode estar mais ou menos preparado para acolher essa energia. Do ponto de vista da teoria elaborada por ele aqui, a angústia é um mecanismo de preparação que torna o sistema psíquico mais apto a receber uma carga de energia potencialmente traumática, sem, contudo, sofrer um abalo efetivamente traumático. Com isso se explica, ao menos parcialmente, os sonhos neuróticos em que o indivíduo é reiteradamente recolocado na situação traumática que originou a neurose, ao mesmo tempo em que a antiga teoria do sonho como realização de desejos sofre uma forte limitação:

Se os sonhos dos neuróticos que sofreram acidentes fazem os doentes voltarem regularmente à situação do acidente, então eles não se acham a serviço da realização de desejos, cuja satisfação alucinatória tornou-se, sob o domínio do princípio do prazer, função dos sonhos. Mas podemos supor que desse modo eles contribuem para outra tarefa, que deve ser resolvida antes que o princípio do prazer possa começar seu domínio. Tais sonhos buscam lidar retrospectivamente com o estímulo, mediante o desenvolvimento da angústia, cuja omissão tornara-se a causa da neurose traumática. Assim, nos permitem vislumbrar uma função do aparelho psíquico que, sem contrariar o princípio do prazer, é independente dele e parece mais primitiva que a intenção de obter prazer e evitar desprazer ${ }^{17}$.

É justamente o caráter primitivo dessa função que leva Freud a localizá-la "além do princípio do prazer”. Na passagem que citamos anteriormente, ele a caracteriza ainda como "mais pulsional" 18 que o princípio do prazer; e, em sintonia com essa caracterização,

\footnotetext{
fenômenos da vida.”

${ }^{16}$ FREUD, Jenseits des Lustprinzips, 28.

${ }^{17}$ FREUD, Jenseits des Lustprinzips, 32.

${ }^{18}$ FREUD, Jenseits des Lustprinzips, 22.
} 
ressalta seu aspecto "demoníaco" (de fato, ele insiste nessa adjetivação!) ${ }^{19}$. O que isso quer dizer? Ora, o "demoníaco" da repetição está justamente em seu caráter pulsional, portanto inconsciente, que faz com que o indivíduo se sinta como que "guiado" ou "manipulado" por uma força que lhe é estrangeira e que o coloca repetidamente na mesma situação dolorosa.

O passo seguinte de Freud é reconduzir essa força pulsional que se manifesta na compulsão à repetição a uma característica geral dos impulsos e, mais ainda, de toda a vida orgânica. O argumento é claramente especulativo e é apresentado em tom hesitante, o que não impede Freud de arriscar uma definição bastante ousada: "Um impulso (Trieb) seria, portanto, um ímpeto (Drang), presente em todo organismo vivo, tendente à restauração de um estado anterior, que esse ser vivo teve de abandonar por influência de perturbadoras forças externas” ${ }^{20}$. Alguns exemplos, extraídos da observação empírica do comportamento de certas espécies animais e de alguns modelos descritivos acerca do desenvolvimento das células embrionárias da embriologia da época, são aludidos em apoio a essa hipótese geral sobre os impulsos. Em particular, os movimentos migratórios de aves e peixes, que buscam os antigos locais de habitação de sua espécie, e os fatos associados à hereditariedade e descritos pela embriologia, nos quais se vê que o desenvolvimento do embrião de uma determinada espécie atual recapitula os mesmos estágios morfológicos pelos quais passaram seus ancestrais no curso de sua história evolutiva ${ }^{21}$ - todos esses exemplos dão testemunho da "natureza conservadora do vivente" e de "uma orgânica compulsão a repetir" ${ }^{22}$.

Uma tese importante apresentada aqui e que deve ser sublinhada é a de que o estado ao qual o organismo anseia por retornar é um estado que ele abandonou sob o efeito de causas externas. Assim, todo o desenvolvimento morfológico e funcional do organismo é reconduzido à influência de fatores que agem sobre ele a partir de fora, e que perturbam sua tendência natural à inércia. A distinção entre interno e externo é fundamental para a argumentação de Freud. O princípio conservador, que tende a manter o organismo em inércia e que, posteriormente, impele-o ao retorno e à repetição, tem seu locus na interioridade do corpo biológico, e a ação das forças externas tem efeito perturbador sobre essa tendência natural.

Da constatação da natureza conservadora dos impulsos deve-se concluir que o objetivo da vida não pode ser um estado nunca antes alcançado. Este talvez seja o momento do texto de Freud em que o vocabulário teleológico se faz presente de forma mais marcante. Lemos ali que as forças orgânicas não aspiram à transformação e ao progresso, mas antes buscam “alcançar uma antiga meta (Ziel) por vias antigas e novas.” O

\footnotetext{
${ }^{19} \mathrm{O}$ adjetivo aparece três vezes no texto, nas páginas 20,36 e 37.

${ }^{20}$ FREUD, Jenseits des Lustprinzips, 38.

${ }^{21}$ Freud se refere aqui à teoria da recapitulação ou lei biogenética, do biólogo darwinista Ernst Haeckel.

${ }^{22}$ FREUD, Jenseits des Lustprinzips, 38-39.
} 
termo Ziel se desdobra então na expressão “objetivo da vida” (Ziel des Lebens), que é finalmente identificado à morte:

Se é lícito aceitarmos, como experiência que não tem exceção, que todo ser vivo morre por razões internas, retorna ao estado inorgânico, então só podemos dizer que o objetivo de toda vida é a morte, e, retrospectivamente, que $o$ inanimado existia antes que o vivente ${ }^{23}$.

Essa importante tese será parcialmente limitada pela contraposição entre aquelas forças que anseiam por um retorno ao inorgânico e um outro grupo de forças, que tendem ao prolongamento da vida, e cuja presença no organismo é igualmente constatável nos processos de reprodução e na subsistência da substância viva pelas células germinativas, que lhe conferem uma espécie de "imortalidade potencial” ${ }^{24}$. Com isso se configura então aquele dualismo fundamental entre pulsões de vida (também chamadas de pulsões sexuais) e pulsões de morte. As primeiras tendem à formação de unidades cada vez maiores de matéria orgânica e à manutenção das condições econômico-energéticas ideais para o desenvolvimento adequado do organismo e sua reprodução pela fusão de duas células germinativas. As segundas, pelo contrário, tendem à desagregação dessas unidades orgânicas e à recondução da substância viva ao estado inorgânico, por um esvaziamento total da energia excitatória.

Apoiando-se no modelo biológico de E. Hering, segundo o qual, "na substância viva, operam ininterruptamente dois tipos de processos, em direções opostas - uns construtivos, anabólicos, os outros destrutivos, catabólicos”, ${ }^{25}$ Freud reconhece, nessas duas direções dos processos vitais, a atividade daqueles dois conjuntos de impulsos. E é nesse momento então que nos deparamos com a citação de Schopenhauer: "há outra coisa que não podemos ignorar: que inadvertidamente adentramos o porto da filosofia de Schopenhauer, para quem a morte é 'o autêntico resultado' e, portanto, o objetivo da vida, enquanto o instinto sexual é a encarnação da vontade de vida” 26 .

O trecho citado de Schopenhauer se encontra entre aspas, e Freud nos fornece a referência em uma nota. Para viabilizar a análise de contexto, citarei aqui a passagem de Schopenhauer na íntegra:

Assim, aquela direção invisível, manifesta apenas em aparência duvidosa, nos conduz até a morte, esse verdadeiro resultado e, nessa medida, verdadeiro fim $(Z w e c k)$ da vida. $\mathrm{Na}$ hora da morte, todos os poderes misteriosos (apesar de enraizados verdadeiramente em nós mesmos) que determinam o eterno destino do homem se conjugam e entram em ação. De

\footnotetext{
${ }^{23}$ FREUD, Jenseits des Lustprinzips, 40.

${ }^{24}$ FREUD, Jenseits des Lustprinzips, 42.

${ }^{25}$ FREUD, Jenseits des Lustprinzips, 53.

${ }^{26}$ FREUD, Jenseits des Lustprinzips, 53.
} 
seu conflito se produz o caminho que ele deve agora percorrer, isto é, prepara-se sua palingenesia, junto com todo o curso de prazeres e dores nela contido e que agora o determina inexoravelmente. Nisso se baseia o caráter sumamente sério, importante, solene e terrível do momento da morte. Ele é uma crise (Krisis), no sentido mais forte da palavra, - um juízo final (Weltgericht). (P I, 250)

Essa passagem, que teremos ocasião de analisar mais detidamente na sequência, encerra o texto de Schopenhauer após uma longa reflexão, de teor ainda mais especulativo que as de Freud, sobre as forças que aparentemente guiam o indivíduo para a realização do que seria seu destino. É curioso notar, como observa Zentner ${ }^{27}$, que Freud se vale de um texto de Schopenhauer sobre o destino, mas não para dar suporte às suas hipóteses sobre o “destino demoníaco" que parece conduzir os indivíduos à repetição das mesmas vivências dolorosas em seu curso de vida, mas sim para ilustrar seu modelo pulsional: não apenas sua tese sobre a pulsão de morte, mas seu dualismo pulsional como um todo. É verdade que a expressão schopenhaueriana que descreve a morte como o "verdadeiro resultado" e o “verdadeiro fim da vida” está, à primeira vista, muito próxima da afirmação freudiana: “o objetivo de toda vida é a morte”. Essa proximidade pode nos levar a supor, além da mera concordância terminológica e lexical, uma concordância conceitual e de conteúdo. Ainda que essa leitura estivesse correta (adiante tentaremos mostrar que, na verdade, ela é fruto de um equívoco), nada há no texto citado que autorize a atribuição a Schopenhauer de um dualismo pulsional nos moldes do dualismo freudiano. Mas Freud parece estar atento a isso, razão pela qual ele reserva as aspas ao trecho em que a morte é apresentada como o "verdadeiro resultado" da vida, colocando a referência logo ao fim dessa sentença, e complementando sua frase com uma síntese brevíssima da concepção schopenhaueriana da sexualidade, extraída de outros textos que não são referenciados ${ }^{28}$. Podemos concluir daí que Freud tem em vista não apenas esse texto específico de Schopenhauer (no qual, vale notar, nada é dito sobre a sexualidade e a afirmação da vida), mas sim a metafísica da vontade em geral, que inclui sua metafísica da natureza, a metafísica do amor sexual, a metafísica da morte e a metafísica da moral como um todo, da qual a metafísica da morte é apenas uma parte. Isso nos autoriza então a contextualizar a passagem citada no horizonte conceitual do voluntarismo tomado globalmente.

\footnotetext{
${ }^{27}$ ZENTNER, “Das Ziel alles Lebens ist der Tod”. Schopenhauer und Freuds Todestrieb, 325.

${ }^{28}$ Sobre o tema da sexualidade em Schopenhauer e sua proximidade com as teses de Freud, cf. GÖDDE, Traditionslinien des Unbewussten. Schopenhauer - Nietzsche - Freud, 398ss.; cf. ainda FONSECA, Psiquismo e vida. Sobre a noção de Trieb nas obras de Freud, Schopenhauer e Nietzsche (em especial as seções II.7 e II.8) e FONSECA, Sexualidade e morte em Schopenhauer: o abismo insondável da vontade.
} 
Tendo isso em vista, perguntemos antes de mais nada: qual sentido devemos atribuir à expressão schopenhaueriana: "a morte, esse verdadeiro resultado e, nessa medida, verdadeiro fim (Zweck) da vida"? No ensaio schopenhaueriano de que se trata aqui, toda a argumentação que conduz a essa conclusão tem por objetivo fornecer suporte especulativo a uma impressão relativamente comum à qual somos conduzidos no confronto com as situações que compõem o curso de nossas vidas: a impressão de que tudo o que acontece conosco, das escolhas mais deliberadas, passando pelo fracasso dessas escolhas, até os acasos mais fortuitos, acontece por algum motivo, por alguma razão que desconhecemos. A tese geral de que “tudo acontece por uma razão" é desdobrada por Schopenhauer em duas formulações, às quais ele dá o nome de fatalismo demonstrável e fatalismo transcendente. $O$ primeiro se refere à tese, cuja verdade é demonstrada claramente pela razão e pela ciência, de que "tudo o que acontece, sem exceção, acontece com rigorosa necessidade". (P I, 227) Assim, a afirmação geral de que 'tudo acontece por uma razão' se traduz, no âmbito da primeira formulação, na afirmação de que todos os fenômenos do mundo se inserem numa cadeia de causas e efeitos determinada, em que cada causa é a razão suficiente do efeito que ela produz. Essa lei abrange todos os fenômenos, sem exceção, da queda de uma pedra à ação racional, e cada classe de objetos distingue-se das outras apenas em função da figura do princípio de razão que rege a conexão necessária dos fenômenos que recaem sob seu escopo (o princípio de razão do devir, do ser, do conhecer e do agir) ${ }^{29}$. Disso se conclui que aquilo a que chamamos "acaso" não é senão o produto de uma conjunção de eventos absolutamente necessários, mas cujas variáveis causais nos escapam inteiramente. Todos os supostos acasos que ocorrem na natureza em geral e na vida dos indivíduos em particular são regidos por essa necessidade invariável da série causal dos fenômenos como um todo.

Já o segundo fatalismo, ao qual Schopenhauer dá o nome de "fatalismo transcendente", supõe ainda, por trás dessa necessidade causal que integra os fenômenos num todo regido por leis naturais, um plano que se realizaria na vida individual de cada pessoa, e que articularia entre si todas as suas decisões, indecisões, impulsos, acertos e

\footnotetext{
${ }^{29}$ Essa enumeração das figuras do princípio de razão não está presente no texto sobre a Especulação transcendente, mas se encontra implícita no argumento e é indiretamente referenciada pela menção que faz Schopenhauer ao seu livro Sobre a liberdade da vontade, no qual a análise das figuras do princípio de razão tem um papel central. Em vez de apresentar, para a justificação do fatalismo demonstrável, uma descrição detalhada de cada uma das figuras nas quais a conexão necessária entre os fenômenos se apresenta, Schopenhauer opta por enumerar uma série de fenômenos de vidência, como sonhos proféticos, oráculos, leitura de astros, além de apresentar o exemplo da tragédia de Édipo Rei, entre outros (P I, 227s.). Cf. sobre isso também DEBONA, Destino e fatalismo em Schopenhauer, 85. Para uma interessante discussão sobre o uso que Schopenhauer faz desses fenômenos "paranormais” em sua metafísica, cf. SILVA, Metafísica prática em Schopenhauer (os fenômenos da vidência e da “segunda visão” são analisados na seção 5.4.).
} 
erros a um conjunto de eventos exteriores que a conduziriam necessariamente a uma meta. O sentido dessa meta, por sua vez, transcende inteiramente o conhecimento teórico que fundamenta a tese do fatalismo demonstrável, e igualmente escapa, a princípio, ao conhecimento e à consciência do próprio indivíduo. Trata-se de um sentido ao mesmo tempo metafísico e moral, que Schopenhauer não explicita ainda nesse momento do texto, deixando-o indeterminado. Na perspectiva do fatalismo transcendente, o curso de vida do indivíduo se desdobra e se revela, aos poucos, como um todo atravessado por uma tendência moral e dotado de "sentido pedagógico" (belehrenden Sinn), comparável à mais bem elaborada narrativa épica (P I, 229). Essa revelação faz nascer no indivíduo a convicção de que "a necessidade de tudo o que acontece não é uma necessidade cega" (P I, 228), com o que surge então a crença naquele "fatalismo de tipo superior". Como indicado, porém, ao contrário do fatalismo demonstrável, o fatalismo transcendente jamais pode ser epistemicamente justificado. Ele se apresenta como uma visão de mundo que, diante do modo como as circunstâncias da vida nos conduzem, insiste em se insinuar a nós, à revelia dos argumentos racionais de que dispomos contra sua aceitação ${ }^{30}$.

Segundo Schopenhauer, esse plano que se revela no curso de vida de uma pessoa pode ser, em grande parte, explicado pela imutabilidade do caráter da pessoa, que é inato e cujas raízes são metafísicas: trata-se do caráter inteligível, um ato atemporal da vontade cósmica que dá forma e individualiza, numa ideia própria, os traços específicos que constituem a personalidade de cada ser humano ${ }^{31}$. Se os atos do ser humano são sempre produtos necessários de seu caráter imutável (cuja instanciação empírica responde aos motivos sempre segundo uma regra pré-determinada), então é compreensível que o indivíduo seja sempre reconduzido à mesma trilha (P I, 230) ${ }^{32}$. De fundamental importância, nesse contexto, é a tese de que o caráter inteligível, que determina

\footnotetext{
${ }^{30}$ Para ilustrar essa visão, Schopenhauer cita um trecho do epistolário do poeta Knebel: "Numa observação mais atenta, descobre-se que, na vida da maioria dos homens, encontra-se um certo plano, traçado por sua própria natureza ou pelas circunstâncias que a conduzem. As situações de suas vidas podem ser as mais instáveis e mutáveis, mas ao final mostra-se um todo sob o qual se percebe certa concordância. A mão de um destino determinado, por mais secretamente que atue, revela-se perfeitamente, não importa se é movida por efeitos externos ou por impulso interno: mesmo as razões mais contrárias se movem frequentemente em sua direção. Por mais confuso que seja o curso, ele revela sempre uma razão e uma direção." (Knebel's litterarischer Nachlaß. 2. Aufl. 1840. Bd. 3. S.452, apud. SCHOPENHAUER, P I, 230)

${ }^{31}$ Para uma análise detida sobre a noção de "caráter" no pensamento de Schopenhauer, cf. DEBONA, Um caráter abissal - a metafísica schopenhaueriana da Vontade como caracterologia, e DEBONA, A propósito da noção de "caráter": as presenças de Kant e Schelling na tese de doutorado de Schopenhauer.

${ }^{32}$ É bastante clara, aqui, a proximidade com relação à concepção freudiana da repetição das experiências na vida do indivíduo, como determinada por um destino que se manifesta como um tipo de "poder demoníaco". Sobre isso, cf. ainda ATZERT, Zwei Aufsätze über Leben und Tod: Sigmund Freuds Jenseits des Lustprinzips und Arthur Schopenhauers Transscendente Spekulation über die anscheinende Absichtlichkeit im Schicksal des Einzelnen, 190; e ZENTNER, "Das Ziel alles Lebens ist der Tod”. Schopenhauer und Freuds Todestrieb, 325 .
} 
necessariamente o caráter empírico, é a priori inteiramente inconsciente. Ele pertence à dimensão metafísica da vontade, que se encontra, por definição, para além de todas as fronteiras da cognição e da consciência individual. Nesse sentido, as ações que conduzem o indivíduo por aquele caminho pré-determinado não resultam de um conhecimento consciente acerca do que seria mais adequado à realização de sua meta, mas emergem espontaneamente e de forma instintiva a partir de sua interioridade mais profunda, portanto inconscientemente, de modo que o indivíduo dificilmente será capaz de prestar contas dos motivos ou das razões últimas que o levaram a um determinado caminho, que era de fato o mais apropriado para ele. E isso ocorre mesmo quando o caminho que o indivíduo é compelido a seguir, pela pressão das circunstâncias externas, contradiz à primeira vista seus desejos (isto é, aquilo que ele acreditava serem os meios adequados para a realização de seus fins) e o submete a uma série de sofrimentos e provações. Para Schopenhauer, isso revela a intervenção daquela força estrangeira (fremde Macht) que guia o ser humano:

acreditamos ser os senhores de nossos atos a todo momento. Contudo, se olhamos retrospectivamente para o curso pregresso de nossa vida e contemplamos nossos passos infelizes, juntamente com suas consequências, frequentemente não conseguimos entender como pudemos ter feito isto ou deixado de fazer aquilo; de modo que parece que uma força estrangeira guiou nossos passos. (P I, 233)

O texto schopenhaueriano permite deduzir que essa força estrangeira, esse "poder oculto e inexplicável” (geheime und unerklärliche Macht, P I, 235) possui duas dimensões. A primeira delas está bastante explícita na argumentação e se refere, como indicado, ao caráter inteligível, que Schopenhauer associa ao campo semântico do daimon na língua grega, e do genius na língua latina, ilustrando essa ideia, por analogia, mediante vários exemplos da filosofia e da mitologia antigas, da religião e da literatura moderna. A segunda dimensão não se encontra tão explicitada no texto e, por vezes, parece se fundir à primeira. Trata-se da dimensão da própria vontade cósmica, que engloba, enquanto totalidade, não apenas todos os caracteres individuais, mas todas as forças que regem os fenômenos naturais em geral. Nos momentos em que aparece da forma mais clara, essa dimensão é indicada pela analogia com a teleologia da natureza (P I, 238).

O tema é retomado explicitamente do capítulo 26 dos Complementos ao Mundo (W II, § 26), que por sua vez se conecta diretamente ao parágrafo 28 do primeiro tomo (W I, § 28). Nesses textos, Schopenhauer distingue dois tipos de finalidade na natureza: a interna e a externa. A primeira diz respeito à coordenação recíproca entre as partes de um organismo, responsável pela manutenção de sua forma e por seu desenvolvimento regulado a partir de um trabalho conjunto de todos os órgãos e sistemas orgânicos. A tese principal aqui é extraída da segunda parte da terceira Crítica de Kant: esse processo de coordenação 
e de autorregulação das partes do organismo não é explicável por remissão à mera causalidade mecânica (a causa eficiente), mas exige o recurso a uma explicação teleológica (a causa fina) (W II, § 26, 378). O telos, nesse caso, é a realização da forma substancial do organismo em sua totalidade, que corresponde à ideia própria de sua espécie.

O segundo tipo de finalidade, a finalidade externa, é pensada em analogia com a primeira e a expande para a totalidade da natureza. Ela se refere à "relação da natureza inorgânica para com a orgânica em geral", mas também à "relação entre si de partes isoladas da natureza orgânica, que torna possível a conservação de toda a natureza orgânica, ou também de espécies isoladas de animais” (W I, § 28, 184). A analogia proposta por Schopenhauer entre finalidade interna e externa parte da constatação de que o surgimento dos organismos pressupõe, do ponto de vista de sua produção material (biogênese), toda a história natural que o antecede e, portanto, todas as formas da natureza anteriores ao seu aparecimento, pois são elas que fornecem as condições materiais para sua produção segundo uma conjunção de causas e efeitos, que é pensada aqui como orientada por um princípio teleológico, assim como as partes do organismo trabalham conjuntamente para seu pleno desenvolvimento e para expressão acabada de sua forma substancial ou ideia. Trata-se aqui do "apoio" e da "ajuda” que todos os organismos "recebem de fora, tanto da natureza inorgânica quanto uns dos outros" (W I, § 28, 188). O que Schopenhauer tem em vista, nesse sentido, é que, assim como a ideia do organismo contém a unidade inteligível e paradoxalmente atemporal de todos os seus desenvolvimentos temporais, a unidade da vontade que se manifesta na totalidade da natureza contém em si a unidade inteligível de todos os desenvolvimentos temporais de todas as suas partes, desde a natureza inorgânica até o ser humano ${ }^{33}$. Nesse sentido, podese dizer que cada ato da vontade, enquanto produto daquela unidade inteligível, está orientado para uma finalidade. Mas qual é essa finalidade? A resposta a essa pergunta dependerá do foco da leitura e do peso que se concede a certos textos e a certas partes do sistema de Schopenhauer. No caso do texto sobre a aparente intencionalidade no destino do indivíduo, o leitor precisará aguardar até as últimas linhas para ter uma ideia clara do que o autor tem em vista aqui. Mas antes de nos debruçarmos sobre esse problema, cabe retomar rapidamente o fio condutor do argumento geral.

É essa segunda forma de finalidade, a finalidade externa, que serve de modelo ao filósofo em sua tentativa de refletir sobre a concatenação planificada dos eventos no curso de vida do indivíduo e, mais ainda, de todos os cursos de vida individuais e de todos os eventos da vida animal e vegetal, juntamente com os processos físicos e químicos no mundo inorgânico, já que todos estes estão incluídos entre as variáveis causais que compõem a série total dos fenômenos do mundo. Schopenhauer chega a falar numa "harmonia pré-estabelecida (harmonia praestabilita)" (P I, 246) entre os destinos dos

\footnotetext{
${ }^{33}$ Discuto em mais detalhes esses temas em MATTIOLI, O paradoxo das causas finais: Schopenhauer leitor da "Crítica do juízo teleológico", 222ss.
} 
indivíduos e as cadeias causais dos processos naturais. Dessa especulação sobre a ligação sistemática de tudo no todo, ele crê poder extrair uma explicação para a possibilidade dos presságios (P I, 247s.), aquela capacidade que possuem alguns indivíduos de lerem, nos processos e figuras naturais (o voo dos pássaros, o desenho dos borrões de café, etc.), a ocorrência de acontecimentos futuros, inclusive na prosaica vida individual. Com efeito, o destino individual é parte do destino do todo, e a finalidade da vida individual é parte da finalidade da vida do todo.

Com essa última afirmação, retornamos à pergunta fundamental colocada no parágrafo anterior. Qual seria então essa finalidade? Do ponto de vista do destino individual, a maior parte do texto alude de forma muito geral e imprecisa ao "objetivo", à "meta" ou ao "fim" a ser atingido na vida de cada pessoa. Schopenhauer usa os termos Wohl, Beste e gut, todos associados ao "bem”, àquilo que é "bom” ou "o melhor" para nós. Mas, como dito, no curso de praticamente toda a argumentação, esses termos são usados de maneira suficientemente indeterminada de modo a deixar o leitor livre para compreendê-los no sentido mais intuitivo para ele. Apesar de caracterizar o fatalismo transcendente sempre como dotado de um sentido metafísico-moral, essa caracterização não é suficiente para fornecer uma determinação mais precisa do sentido do "bem” que é aí visado. Como o sentido mais intuitivo que o leitor minimamente esclarecido associa a esse termo é um sentido eudaimonístico e prudencial, ligado às condições propícias para uma vida boa no sentido de uma vida feliz e virtuosa, essa é a conotação que acaba por prevalecer implicitamente, iluminando boa parte da argumentação mediante a qual Schopenhauer busca nos convencer da existência de um tipo de 'conspiração cósmica' a nosso favor ${ }^{34}$. É apenas nas últimas páginas que nos deparamos com uma tentativa de fornecer uma qualificação um pouco mais precisa do que seria aquela finalidade, aquele "bem” - qualificação com a qual vem abaixo a compreensão intuitiva (eudaimonística) de "bem" que pairava indeterminadamente sobre o argumento geral. Se há alguma finalidade eudaimonística na vida do indivíduo, essa finalidade diz respeito apenas à sua vontade

\footnotetext{
34 "Vida feliz" talvez não seja a expressão mais adequada no contexto do pessimismo schopenhaueriano, mas sim "o menos desprazerosa possível”. Esse é o objetivo buscado por ele na parte de sua filosofia que lida com a "sabedoria de vida", sobre a qual não falaremos aqui (para uma discussão aprofundada deste tema, cf. os trabalhos de DEBONA: Pessimismo e eudemonologia: Schopenhauer entre pessimismo metafísico e pessimismo pragmático, e A outra face do pessimismo: caráter, ação e sabedoria de vida em Schopenhauer). Gostaria apenas de chamar a atenção para a tradução inglesa de E. F. J. Payne, que traduz por welfare ("bem" no sentido eudaimonístico, ou mesmo utilitário e hedonista, de "bem-estar") os termos Wohl e Beste indicados acima. Schopenhauer analisa o conceito de "bom" (gut, das Gute) e seu uso eudaimonístico, hedonista e utilitário no parágrafo 57 do primeiro tomo do Mundo, sugerindo, na sequência dessa análise, que esse conceito só pode ser empregado figurativa e metaforicamente para indicar o "bem supremo (sumum bonum)" que se realiza com a autossupressão da vontade (W I, § 57, 428). Digna de nota é a observação de Schopenhauer de que, nesse caso, um termo melhor seria o termo grego telos, ou a expressão latina finis bonorum.
} 
empírica, que anseia pela satisfação de seus desejos por intermédio dos objetos que se apresentam como motivos em seu campo de ação possível, no horizonte temporal do mundo como representação. Essa finalidade eudaimonística, contudo, não condiz com o sentido metafísico e verdadeiramente moral da existência humana. Cito uma passagem de fundamental importância para se compreender o que Schopenhauer tem mente com essa noção de um sentido e uma finalidade metafísico-moral:

Mas o que era realmente visado, em última instância, por esse desígnio misterioso (geheimnißvolle Lenkung) do curso de vida individual que consideramos aqui, é algo que só se deixa indicar de forma muito geral. Detenhamo-nos nos casos particulares; pode parecer, frequentemente, que ele só visa nosso bem-estar temporal e momentâneo. Este, porém, devido à sua insignificância, imperfeição, futilidade e transitoriedade, não pode ser seriamente o seu fim último: portanto, temos de procurá-lo em nossa existência eterna, que ultrapassa nossa vida individual. E então só podemos dizer de modo muito geral que nosso curso de vida é regulado por aquele desígnio de tal forma que, de todo o conhecimento que alcançamos através dele [do nosso curso de vida, W.M.], brota o efeito metafisicamente mais adequado (zweckdienlichste) sobre a vontade, como o núcleo e a essência em si do ser humano. [...] Uma vez que reconhecemos, a partir dos resultados da minha filosofia da seriedade (Philosophie des Ernstes) ${ }^{35}$ [...], que o fim último (letztes Ziel) da existência temporal é a recusa da vontade de vida, então temos de admitir que cada um é, aos poucos, guiado a esse fim do modo que lhe é mais apropriado, muitas vezes por meio de longos desvios. Ademais, uma vez que felicidade e prazer são, na verdade, contrários a essa meta $(Z w e c k)$, vemos que, de acordo com isso, todo curso de vida é inevitavelmente atravessado pela infelicidade e pelo sofrimento ( $P$ I, 249s.).

Com isso, estamos finalmente em condições de compreender a sentença final citada por Freud, segundo a qual a morte é o "verdadeiro resultado e, nessa medida, o verdadeiro fim da vida." (P I, 259) "Resultado" deve ser entendido aqui a partir de seu sentido vernacular original: como o produto de um cálculo, um cômputo geral que mostra sinteticamente a somatória de tudo o que a vida nos deu. A expressão: "o verdadeiro resultado da vida" faz referência ao fato de que tudo o que podemos extrair da vida, a despeito de todos os nossos esforços, é a morte. Se realizamos nossos sonhos, realizamolos apenas para que sejam ao fim tragados pela morte; se desfrutamos de alguma felicidade nesse caminho tortuoso, ela é ligeira e inevitavelmente será destruída pela morte;

\footnotetext{
${ }^{35}$ Schopenhauer se refere à quarta parte de seu sistema no Mundo como vontade e representação, dedicada à ética. No início do quarto livro do primeiro tomo, ele diz tratar-se da "parte mais séria" de toda sua filosofia (W I, § 53, 319).
} 
quaisquer que sejam os objetivos e resultados que buscamos alcançar com nossos esforços nessa vida, eles se tornam vãos e destituídos de sentido frente a este que é o único verdadeiro resultado do processo em que nos encontramos: a morte. Vista objetivamente, "a vida da maioria das pessoas é tão somente uma luta constante por essa existência mesma, com a certeza de ao fim serem derrotadas” (W I, § 57, 368). Dessa constatação em grande medida empírica (trata-se de um sentimento concreto em face da expectativa iminente da morte biológica do corpo, do desaparecimento do indivíduo), Schopenhauer se encaminha então para uma tese que ultrapassa o plano da empiria, lançando-nos em direção ao sentido ético e metafísico da existência: a morte é, em última instância, o "objetivo" da vida, pois ela nos possibilita uma consciência da radical falta de sentido do mundo e da vida e abre, assim, as portas para a realização da redenção pela negação da vontade de vida. Tomemos uma passagem do importante capítulo 49 dos Complementos ao mundo, intitulado: “A ordem da salvação”, que se relaciona diretamente a essas reflexões:

A morte é o resultado, o resumé da vida, ou a soma final que expressa de uma vez todo o ensinamento (Belehrung) que a vida dera parcial e fragmentariamente, a saber, que toda aspiração, cujo fenômeno é a vida, foi algo vão, fútil, contraditório consigo mesmo, e a ela renunciar consiste numa redenção. (W II, § 49, 730)

Dito isso, temos de nos colocar a pergunta: será que a menção que Freud faz à afirmação de Schopenhauer, no contexto de sua discussão sobre a pulsão de morte, restitui corretamente seu sentido? Concordo com Marcel Zentner ${ }^{36}$ que a resposta mais correta a essa pergunta é não. Mas isso não quer dizer que não haja, a despeito de uma diferença absolutamente fundamental, um ponto de contato importante entre a meta que Freud atribui à pulsão de morte e o sentido que Schopenhauer atribui ao efeito deflagrado pela experiência da morte. É à análise desse conjunto de questões que nos dedicaremos a partir de agora.

\section{III}

No já mencionado artigo de Zentner, intitulado: “'Das Ziel alles Lebens ist der Tod'. Schopenhauer und Freuds Todestriebe”37, o autor argumenta que a suposta concordância

\footnotetext{
${ }^{36}$ ZENTNER, “Das Ziel alles Lebens ist der Tod”. Schopenhauer und Freuds Todestrieb, 326ss.

${ }^{37} \mathrm{O}$ artigo foi recentemente traduzido para o português com o título: “'O objetivo de toda a vida é a morte’ Schopenhauer e o instinto de morte de Freud”, no volume 9, n. 2, da Revista Voluntas (2018). A tradução é de responsabilidade de Guilherme Marconi Germer e conta com uma pequena apresentação, na qual Germer destaca sobretudo as críticas de Zentner à aproximação estabelecida tradicionalmente entre o modelo da volição de Schopenhauer e o modelo das pulsões de vida e morte de Freud, a partir de uma recusa do dualismo por parte de Schopenhauer, como consequência de seu monismo metafísico. Ele ainda busca
} 
conceitual e de conteúdo entre a afirmação freudiana de que "o objetivo de toda vida é a morte" e a expressão schopenhaueriana que caracteriza a morte como "o verdadeiro resultado e, nessa medida, o verdadeiro fim da vida”, se baseia numa interpretação equivocada da sentença de Schopenhauer por parte de Freud, e que foi reproduzida de modo um tanto quanto acrítico pelos comentadores. O primeiro passo de seu argumento é considerar que a passagem citada por Freud só pode ser compreendida sob o pano de fundo da metafísica da vontade como um todo. Admitido esse passo, deveríamos ter em mente que, nos textos de Schopenhauer, a morte é, de fato, frequentemente aludida como meta ou objetivo da vida, mas isso se dá ao lado de várias outras ocorrências sobre o “objetivo da vida”, nas quais este é identificado a outras coisas, como por exemplo o autoconhecimento (que é, ao meu ver, o mais importante dos exemplos citados por Zentner $)^{38}$. Na sequência, o comentador apresenta aquele que me parece ser o ponto principal de seu argumento: se, em Freud, a expressão “Ziel des Lebens” tem um sentido claramente teleológico e biológico, extraído da constatação da existência de um impulso orgânico que tende ativamente à morte, esse não seria de modo algum o sentido que Schopenhauer atribui à expressão "Zweck des Lebens". No primeiro caso, trata-se de uma finalidade biológica; já no segundo, trata-se de um sentido ético e pedagógico. Do ponto de vista semântico, a referência é sobretudo ao sentido ou à significação moral que podemos atribuir à vida e à existência a partir da consciência, da experiência ou do momento da morte. Zentner insiste que, para Schopenhauer, a morte jamais indica um "fim" da vida em sentido biológico, e que, à luz de sua ética e de sua doutrina da redenção, devemos compreendê-la no sentido de um ensinamento moral.

Stephan Atzert, por sua vez, num artigo intitulado: "Zwei Aufsätze über Leben und Tod: Sigmund Freuds Jenseits des Lustprinzips und Arthur Schopenhauers

minimizar a oposição, que será destacada aqui, entre as leituras de Zentner e Atzert, com base no argumento de que ambos reconhecem "que o fim ético ao qual a vontade schopenhaueriana se conduz a si própria não é a morte, como Freud lhe atribui equivocadamente, mas a renúncia interna da Vontade, promovida diante da morte” (GERMER, Apresentação à tradução de “O objetivo de toda a vida é a morte” - Schopenhauer e o instinto de morte de Freud, de Marcel Zentner, 152, nota 4). Minha leitura, na esteira de Zentner, sublinha a incompatibilidade entre o modelo biológico freudiano, pelo qual se orienta a argumentação de Atzert, e o modelo ético-metafísico, do "fatalismo transcendente", defendido por Schopenhauer. Mas ela minimiza a oposição entre dualismo das pulsões e monismo da vontade. Em artigo igualmente recente, Germer critica a leitura de Zentner segundo a qual a morte não seria o fim último, mas um meio para esse fim: a negação da vontade (GERMER, A concepção de morte em Schopenhauer, 82s.). Discordo dessa crítica, pelas razões que apresentarei na sequência.

${ }^{38}$ Cf. W I, § 70, 485: “o mundo é autoconhecimento da vontade”. Sobre esse tema, cf. KOßLER, „Das Leben ist nur ein Spiegel“ - Schopenhauers kritischer Lebensbegriff (traduzido para o português no volume 11, n. 2 da Revista Ethic@ (2012): “A vida é apenas um espelho” - o conceito crítico de vida de Schopenhauer); cf. ainda MALTER, Der eine Gedanke. Hinführung zur Philosophie Arthur Schopenhauers, 32s; MALTER, Schopenhauers Transzendentalismus; MATTIOLI, “Dem Willen zum Leben ist das Leben gewiß’: vida e finalidade em Schopenhauer, 206ss. 
Transscendente Spekulation über die anscheinende Absichtlichkeit im Schicksal des Einzelnen”, busca reabilitar, ante as objeções de Zentner, a leitura tradicional que insiste na proximidade entre as teses sobre a vida e a morte de Freud e Schopenhauer. Contra Zentner, ele argumenta que, em Schopenhauer, a direção do curso de vida individual, cujo destino inevitavelmente conduz à morte, pode ser sim entendida num sentido teleológico e biológico, semelhante à pulsão de morte freudiana. O ponto de partida de sua leitura é uma expansão do escopo comparativo, que vai além da passagem citada por Freud, não para retomar outros textos do corpus schopenhaueriano, como faz Zentner, mas para retomar e aprofundar a discussão em torno do argumento geral sobre o destino, presente nesse mesmo texto. Ele sublinha que, tanto em Schopenhauer quanto em Freud, o indivíduo se sente compelido por uma força estrangeira, demoníaca, e que essa força provém de sua própria interioridade mais profunda, que permanece oculta à consciência. Além disso, haveria, em ambos os autores, um mesmo traço determinante desse destino demoníaco: a sujeição do indivíduo a experiências de sofrimento. Essas experiências funcionariam, no caso de Schopenhauer, como uma espécie de "preparação para a morte”. Atzert concede a Zentner que esse elemento de sofrimento no curso de vida, e a própria morte à qual esse curso de vida conduz, possuem um caráter pedagógico e um sentido moral e metafísico. Mas ele recusa que esse sentido metafísico seja inconciliável com o sentido da finalidade biológica presente na pulsão de morte: "mesmo considerando-se o sentido de uma 'vontade metafísica de preparação para a morte’, essa vontade poderia se tornar inteiramente, sem grandes esforços - apenas despida de seu aspecto metafísico -, uma pulsão de morte biológica" 39 .

Discordo deste último argumento de Atzert, segundo o qual poderíamos conceber uma "vontade de morte" schopenhaueriana à parte de seu aspecto metafísico, com o que ela se equivaleria à pulsão de morte freudiana. No meu entender, Zentner tem razão ao insistir na absoluta irredutibilidade do significado metafísico da morte à sua dimensão biológica. Nesse sentido, sua leitura está fundamentalmente correta.

Para sustentar minha concordância com a leitura de Zentner, retomo a passagem do capítulo 49 dos Complementos, citada anteriormente, em que Schopenhauer emprega igualmente a expressão "fim [ou objetivo] da vida" para caracterizar a morte (W II, § 49, 730). Aqui, a tese de que a morte é “o fim propriamente dito da vida” se baseia em seu potencial deflagrador da redenção pela renúncia à vida, pela negação da vontade. Notemos então que, nesse trecho, assim como no trecho que antecede imediatamente a passagem focal de Especulação transcendente (também já citado anteriormente), a morte é concebida como um "fim”, tendo em vista, na verdade, um fim ainda mais elevado: a redenção através

\footnotetext{
${ }^{39}$ ATZERT, Zwei Aufsätze über Leben und Tod: Sigmund Freuds Jenseits des Lustprinzips und Arthur Schopenhauers Transscendente Spekulation über die anscheinende Absichtlichkeit im Schicksal des Einzelnen, 190.
} 
da negação da vontade. Schopenhauer remete aos resultados de sua ética (sua "filosofia da seriedade”), para sustentar que "o fim último (letztes Ziel) da existência temporal é a recusa da vontade de vida (Abwenden des Willens vom Leben)" ${ }^{40}$ (P I, 249s.). O argumento geral que se expressa nesses textos é o de que a morte se revela como um momento fundamental no processo de negação da vontade, ao agir como uma espécie de catalisador da redenção. O momento da morte produz um olhar retrospectivo sobre o curso completo da vida e tem um efeito radical sobre a vontade que se objetiva na moribunda individualidade, capaz de convertê-la e dar-lhe uma nova direção. Esse olhar retrospectivo produz a consciência da vanidade de todo esforço e da nulidade da vida, constituindo assim seu resultado moral e essencial. Aí estão dadas as condições a partir das quais a vontade se nega e pode renunciar por completo à vida. “À vontade que não se nega, cada nascimento lhe confere um novo e diferente intelecto - até que a vontade reconhece a verdadeira índole da vida e, em consequência disso, não mais a quer.” (W II, § 49, 730)

Esta última passagem, do capítulo “A ordem da salvação”, é muito interessante, pois retoma um tema que, apesar de permanecer no plano de fundo, é de grande importância para a metafísica da moral em geral, e para a metafísica da morte em particular: o tema da palingenesia. A importância desse tema é tanto maior para o escopo da análise aqui proposta, na medida em que ele reaparece na passagem de Especulação transcendente que está na base de nossa discussão:

$\mathrm{Na}$ hora da morte, todos os poderes misteriosos (apesar de enraizados verdadeiramente em nós mesmos) que determinam o eterno destino do homem se conjugam e entram em ação. De seu conflito se produz o caminho que ele deve agora percorrer, isto é, prepara-se sua palingenesia, junto com todo o curso de prazeres e dores nela contido e que agora o determina inexoravelmente. (P I, 250, grifo nosso)

No segundo volume dos Parerga e paralipomena, no ensaio intitulado: Sobre a doutrina da indestrutibilidade de nosso ser verdadeiro pela morte, Schopenhauer apresenta sua concepção da palingenesia, inspirada nas religiões orientais, nos seguintes termos: a palingenesia é "a decomposição e a nova formação do indivíduo, que mantendo apenas sua vontade e assumindo a figura de um novo ser, recebe um novo intelecto” (P II, X, § 140, $302)^{41}$. A vontade do indivíduo à qual Schopenhauer se refere aqui é seu caráter inteligível, que, como vimos, corresponde àquela "força demoníaca" aludida no ensaio sobre a

\footnotetext{
${ }^{40}$ A expressão alemã Abwenden des Willens vom Leben talvez fosse melhor traduzida por: "afastamento da vontade com relação à vida", "viragem da vontade diante da vida" (cf. W I, § 68, 448). A particularidade dessa opção de tradução é que ela coloca a vontade como sujeito da ação, retirando-a da condição direta de objeto negado. Nesse caso, não se trata exatamente de uma negação da vontade de vida por parte de um sujeito outro (o puro sujeito do conhecimento?), mas da negação da vida por parte da vontade. Não creio que isso seja mero preciosismo ou sutileza inócua.

${ }^{41}$ Tradução de Flamarion Caldeira Ramos, Sobre a ética §140, 128.
} 
Especulação transcendente, que guia o destino de cada um. Esse caráter é “imortal”, o que significa que ele não é destruído pela morte biológica. Dele se podem predicar as mesmas características da eternidade e da atemporalidade que se predicam da forma substancial das espécies animais e vegetais e de todas as forças primordiais da natureza, ou seja, de todas as ideias em geral. Dentre essas características não se encontram a consciência e o intelecto, cuja condição material é o próprio organismo (mais especificamente, o cérebro), razão pela qual o filósofo distingue sua concepção da palingenesia da teoria da metempsicose, na qual aquilo que sobrevive à morte do corpo biológico é a parte intelectiva da alma. Para Schopenhauer, a parte que sobrevive e que retorna reiteradamente no ciclo de nascimento e morte é a parte pulsional da alma, isto é, sua vontade (W II, § 41, 573s.) $)^{42}$.

Mas o aspecto que mais me interessa na concepção schopenhaueriana da palingenesia é sua tese acerca das condições que determinam o retorno ou o não-retorno do caráter inteligível ao ciclo da vida temporal. E isso porque, no momento da morte, os poderes misteriosos que atuaram na realização do destino do indivíduo se conjugam e concorrem para a formação do juízo que deve responder à pergunta mais fundamental e decisiva de toda existência: 'queres a vida mais uma vez?'. Uma resposta afirmativa recoloca o indivíduo (como caráter inteligível) no eterno ciclo de nascimento e morte. Uma resposta negativa, por sua vez, resulta na supressão de sua vontade, de seu caráter inteligível, e o redime da existência por toda a eternidade.

Segundo Schopenhauer, cada ciclo de vida que o caráter inteligível percorre num corpo individual, sujeito às misérias e aos acasos funestos do mundo, serve para lhe ensinar não apenas que esta vida não vale a pena, mas que a vida em si não vale a pena, até que ele diga a si mesmo, desde o fundo do coração: "Basta desse jogo". (W II, § 41, 546) Desse ponto de vista, todo sofrer “possui em potência uma força santificadora” (W I, § 68, 468); ele configura aquilo que Schopenhauer considera ser uma "segunda via" para a redenção: a via do sofrimento intimamente sentido, diferentemente da via do conhecimento objetivo do sofrimento ${ }^{43}$. Nesse contexto, a morte assume um papel análogo:

\footnotetext{
${ }^{42}$ Sobre o caráter como a parte pulsional da alma, cf. DEBONA, Um caráter abissal - a metafísica schopenhaueriana da Vontade como caracterologia. Para uma discussão mais detida do tema da palingenesia, cf. ANTONIASSI, A noção de palingenesia na filosofia de Schopenhauer: uma contribuição para os debates sobre o processo de negação da vontade.

${ }^{43}$ Quanto a isso, cf. ainda W II, § 49, 728s.: "não há dúvida de que tudo na vida está disposto a nos [...] convencer que o fim da nossa existência não é sermos felizes. Sim, para quem a contempla nos detalhes e imparcialmente, a vida expõe-se antes como especialmente destinada a que não sejamos nela felizes, na medida em que a mesma, através de toda sua índole, porta o caráter de algo que nos estraga o gosto, que nos repugna, algo que temos de desistir como de um erro, para que o nosso coração seja salvo do vício de gozar, sim, de viver, e renuncie ao mundo. Nesse sentido, seria mais correto colocar o fim da vida antes em nossa dor e não no prazer. Pois [...] quanto mais se sofre, tanto mais se está perto de alcançar o verdadeiro fim da vida, e quanto mais feliz se vive, tanto mais distante fica esse fim. [...] Também o efeito peculiar da tragédia
} 
“a morte, na medida em que é um sofrimento, é um impulso à redenção, mas não a própria redenção" (HNI, 163) ${ }^{44}$. Os contínuos renascimentos do indivíduo "constituiriam então a sucessão dos sonhos de vida de uma vontade em si indestrutível, até que ela, instruída e melhorada mediante tantos e tão diversos conhecimentos sucessivos, em sempre novas formas, se suprimisse a si mesma.” (W II, $\S 41,574$ ). Que a morte seja o fim, a meta ou o objetivo da vida, portanto, se revela como uma verdade metafísica que ilumina em luz profunda o sentido moral da existência:

$\mathrm{Na}$ hora da morte decide-se se a pessoa retorna ao seio da natureza, ou não mais pertence a esta, mas - - -: para essa contraposição falta-nos imagem, conceito e palavra, justamente porque todos estes são tomados da objetivação da vontade [...] Entrementes, a morte do indivíduo é em cada caso a pergunta que repetida e incansavelmente a natureza coloca à vontade de vida: "Tiveste o suficiente? Queres sair de mim?” (W II, § 48, 697)

À luz dos textos citados, pode-se dizer que a morte é antes um meio do que um fim propriamente dito; ou, em outros termos, um fim submetido hierarquicamente a um fim superior devido ao seu potencial catalisador como quietivo da vontade, permitindo ao indivíduo alcançar aquilo que no budismo se chama nirvana (extinção) (W II, § 41, 581), o vazio de vontade (o nada), que os cristãos associam à santidade e concebem como efeito da graça (W I, § 70, 477). No parágrafo 63 do primeiro tomo do Mundo, encontramos uma associação direta entre a noção de nirvana e a doutrina da palingenesia:

A recompensa suprema, que espera os atos mais meritórios e a plena resignação [...] o mito só pode expressar negativamente na linguagem deste mundo, por meio da promessa tantas vezes renovada de não voltar a nascer: non adsumes iterum existentiam apparentem: ou como os budistas [...] exprimem-se: "Tu deves atingir o nirvana, ou seja, um estado no qual não existem quatro coisas, a saber, nascimento, velhice, doença e morte.” (W I, § $63,421)$

O tema da graça, por sua vez, é explorado especialmente no parágrafo 70 , ao final do

\footnotetext{
baseia-se no fundo em que ela rompe aquele erro inato [a crença de que existimos para sermos felizes, W.M.], na medida em que nos ilustra, num grande e vistoso exemplo, o fracasso das aspirações humanas e a vaidade de toda esta existência, revelando assim o sentido mais profundo da vida. [...] Ora, quem, por um ou outro caminho, saiu daquele erro a priori que nos é inerente [...] logo verá tudo sob uma luz diferente e agora encontrará o mundo em harmonia, senão com seus desejos, ao menos com sua intelecção. Os infortúnios de todo tipo e intensidade, embora lhe doam, não mais o surpreenderão; pois compreendeu claramente que dor e aflição trabalham precisamente em vista do verdadeiro fim da vida, a renúncia da vontade". Na sequência dessa passagem, Schopenhauer sugere que podemos reconhecer no fato de que o sofrimento é a "verdadeira destinação" da existência humana até mesmo um "toque de intencionalidade" (W II, § 49,729), o que conecta esse capítulo diretamente ao ensaio sobre a Especulação transcendente.

${ }^{44}$ Apud. ZENTNER, "Das Ziel alles Lebens ist der Tod”. Schopenhauer und Freuds Todestrieb, 328.
} 
quarto livro, e no capítulo 48 dos Complementos. Não me deterei sobre essa discussão aqui $^{45}$, mas gostaria de sublinhar uma importante contraposição que se apresenta nesse contexto: a contraposição entre reino da natureza e reino da graça. Essa contraposição é fundamental para se compreender porque o sentido moral e metafísico da morte é absolutamente irredutível ao seu sentido biológico, como quer Atzert, em oposição a Zentner. O reino da natureza, que engloba todos os fenômenos físicos, químicos, biológicos e psicológicos, assim como todos os processos históricos e sociais, as ações humanas deliberadas e não deliberadas, é dominado pela necessidade que conecta cada causa com seu efeito. Nesse domínio, não há liberdade: tudo o que ocorre ocorre necessariamente, como manifestação da vontade de vida que se afirma em cada fenômeno, submetida ao princípio de razão. Aqui se inclui, obviamente, a morte biológica, a morte do corpo, o desaparecimento do indivíduo. Vale notar, porém, que essa morte biológica não afeta absolutamente a vontade metafísica, que é eterna e atemporal, assim como suas objetidades imediatas: as ideias platônicas. Por trás de todo ciclo de mortes e renascimentos dos indivíduos, paira a vida imortal da espécie, nutrida diretamente da fonte metafísica da vontade de vida. Nesse reino da natureza, manifestação da vontade de vida, a única possibilidade de liberdade é o ato de autossupressão da vontade realizado no indivíduo humano ${ }^{46}$. Mas esse ato não se dá como efeito de uma causa; ele não é o resultado de um motivo que mobilizou a vontade individual segundo a disposição de seu caráter. Ele emerge espontaneamente de um tipo sui generis de conhecimento, cuja condição é um intelecto altamente desenvolvido, dotado da capacidade racional de formar uma imagem de conjunto sobre o todo da vida e de reconhecer a unidade metafísica de todos os seres. Esse é o conhecimento que a vontade atinge de si mesma no ser humano, e mediante o qual ela contempla a si mesma num espelho, vendo-se como a causa incontornável de toda miséria do mundo que ela mesma engendrou. Desse tipo muito particular de conhecimento, não mais submetido às necessidades da vontade empírica (a conservação do indivíduo e a propagação da espécie), brota então aquela flor da liberdade que permite uma "viragem" da vontade:

visto que aquela autossupressão da vontade procede do conhecimento, porém todo conhecimento e intelecção enquanto tais são independentes do arbítrio, segue-se que também aquela negação do querer, aquela imersão na liberdade não é obtida por força de resolução, mas procede da relação mais íntima entre o conhecimento e o querer no homem; chega, em consequência, subitamente e como de fora, voando. Por isso justamente a Igreja denominou esse acontecimento efeito da graça. (W I, § 70, 478s.)

\footnotetext{
45 Para uma investigação detida sobre esse tema, cf. BASSOLI, A negação da Vontade como um efeito da Graça: a redenção na concepção de Schopenhauer.

${ }^{46}$ Vale ressaltar: no indivíduo, e não exatamente pelo indivíduo.
} 
Como se pode notar, a redenção pela negação da vontade só é possível como uma “decidida oposição à natureza”, sendo algo "completamente oposto à orientação natural do gênero humano.” (W II, § 48, 720) Essa é a razão pela qual Zentner, ao argumentar que a morte em Schopenhauer, ao contrário de Freud, jamais pode ser entendida a partir da ideia de uma "finalidade biológica", parece recusar-se também a atribuir a ela um estatuto teleológico, interpretando o termo $Z$ weck em sentido exclusivamente pedagógico e ético. A tese de fundo seria a de uma incompatibilidade entre o sentido ético e pedagógico da morte, por um lado, e seu suposto sentido teleológico, por outro. Essa tese não está de todo incorreta, já que o uso que Schopenhauer faz do conceito de "teleologia” está, em grande parte, circunscrito às reflexões sobre a unidade e a ordenação sistemática dos fenômenos naturais, tanto na natureza orgânica quanto na inorgânica, tendo sempre em vista a manifestação da vontade de vida numa longa série evolutiva de seres cuja complexidade aumenta gradativamente, até alcançar a perfeição. Essa teleologia, portanto, ao menos à primeira vista, está orientada pelo princípio da afirmação da vontade, ao passo que o sentido ético da morte se refere justamente ao seu potencial deflagrador da negação da vontade.

Minha leitura, por outro lado, pretende expandir o escopo da noção de "teleologia”, de modo a fazê-la abarcar não apenas os processos naturais que dão expressão aos atos de afirmação da vontade, mas também a realização final da redenção pela negação da vontade. Para tanto, parto de uma distinção entre duas formas de teleologia no pensamento de Schopenhauer, que parecem estar em permanente rota de colisão, e que eu denomino, respectivamente: teleologia funcional e teleologia ético-soteriológica ${ }^{47}$.

Apesar do texto de Zentner sugerir uma compreensão da noção de teleologia limitada à finalidade biológica (que, na minha leitura, pertence à teleologia funcional), seu argumento geral permite concluir que ele não recusa de fato o estatuto teleológico da

\footnotetext{
${ }^{47}$ A teleologia funcional é aquela a partir da qual se pensa o desenvolvimento e a dinâmica das relações internas das partes dos organismos, assim como sua relação com o restante da natureza, como estando orientados primariamente para a produção, reprodução, manutenção e transmissão da vida e do princípio vital das espécies. Nessa forma de teleologia, a noção de "perfeição" é predicada de um organismo ou de um intelecto animal em função da adequação pragmática de suas formas a essa finalidade. A teleologia éticosoteriológica, por sua vez, é aquela a partir da qual se pensa o desenvolvimento das formas de manifestação da vontade como orientado para a produção de um intelecto superior capaz justamente de se libertar, mediante sua capacidade reflexiva, daquela função pragmática, das necessidades da vontade, e se elevar ao conhecimento do imutável: das ideias como formas eternas a pairar livremente sobre a tormenta dos fenômenos e da vontade como unidade eterna e absoluta de tudo o que existe. Este é o intelecto do filósofo, do gênio e do santo, e é ele que possibilita a realização daquilo que Schopenhauer, em muitos momentos, chama de "fim da nossa existência" ou "sentido mais profundo da vida": a autonegação da vontade resultante de seu pleno autoconhecimento. Para uma discussão mais detalhada desse tema, remeto o leitor a meu artigo: O paradoxo das causas finais: Schopenhauer leitor da "Crítica do juízo teleológico" (em especial 222ss.), onde desenvolvo em mais detalhes a argumentação em torno da distinção entre essas duas formas de teleologia e apresento as referências textuais que a sustentam.
} 
morte, como Zweck, contanto que se compreenda que se trata aqui de uma teleologia sui generis e, mais ainda, que a morte como telos está referida a uma hierarquia de fins na qual ela comparece não como o fim último, mas como um fim subordinado a um fim superior: a negação da vontade ${ }^{48}$. Essa interpretação é compartilhada também por Atzert ${ }^{49}$, o que faz da sua defesa de uma redutibilidade do sentido ético da morte à dimensão da finalidade biológica um ponto fraco no seu argumento que busca reaproximar Schopenhauer e Freud.

\section{IV}

A última seção foi orientada pela questão de saber se a menção que Freud, na apresentação de seu conceito de pulsão de morte, faz à afirmação schopenhaueriana de que a morte é o verdadeiro resultado e o verdadeiro fim da vida, restitui corretamente o sentido dessa sentença. Concordamos com a leitura de Zentner quanto à resposta mais direta a essa questão: não. E isso porque, no caso de Freud, a morte é entendida como "objetivo da vida" no sentido de uma finalidade biológica, determinada por um conjunto de impulsos inerentes à vida orgânica e que atuam a partir de seu interior, impondo caminhos determinados ao seu desenvolvimento, que deve culminar no seu perecimento em virtude de causas internas. Já em Schopenhauer, a finalidade da qual se trata na sentença citada por Freud é uma finalidade de natureza ética, existencial e metafísica que, enquanto tal, só se realiza em oposição direta a toda tendência natural do organismo biológico. O que importa a Schopenhauer, na caracterização da morte como o verdadeiro resultado e fim da vida, não é a morte biológica em si, mas sim o momento da morte, o momento em que o indivíduo responde a si mesmo a mais importante questão existencial que lhe pode ser posta: "valeu a pena? queres a vida mais uma vez?” Ao proclamar livremente, do fundo de seu coração, um decidido “não!”, a vontade metafísica do indivíduo alcança a redenção e se suprime. Aos olhos de Schopenhauer, essa supressão equivale ao nirvana budista. Trata-se de uma nadificação do impulso de vida realizada pela própria vontade; um esvaziamento completo de seu ímpeto de autoafirmação. O que resta? Para os limites da linguagem: o nada - a ausência absoluta. Schopenhauer insiste na incapacidade da imaginação, da razão e do discurso para representar-se esse estado de supressão, justamente porque o mundo inteiro como representação, engendrado pela afirmação da vontade, foi abolido, anulado.

À luz do que acaba de ser dito, retornemos então a Freud. O que significa a morte, em Além do princípio do prazer? Não seria também isso: o esvaziamento total, o nada? Ao que tudo indica, sim. Retomemos o trecho do último capítulo já citado no início deste artigo: a pulsão de morte responde por uma função específica, qual seja, primariamente, a de "tornar o aparelho psíquico isento de excitação". Essa função participaria, assim, "do

\footnotetext{
${ }^{48}$ ZENTNER, "Das Ziel alles Lebens ist der Tod”. Schopenhauer und Freuds Todestrieb, 327.

${ }^{49}$ ATZERT, Zwei Aufsätze über Leben und Tod, 188.
} 
universal empenho de todos os viventes: retornar à quietude do mundo inorgânico" 50 . Não é por acaso que também Freud remete, com referência à expressão de Barbara Low, à noção de nirvana, para caracterizar esse estado de anulação das tensões excitatórias: o “princípio do Nirvana” corresponde à tendência “dominante da vida psíquica” (mas também da vida orgânica), a diminuir, manter constante ou, ainda mais importante, abolir a tensão interna dos estímulos ${ }^{51}$. É a esse estado, ou ao processo que conduz a ele, que nos referimos anteriormente pela noção de esvaziamento.

Demos então um passo atrás em nossa análise e reconsideremos brevemente as proximidades entre os dois autores. Há um importante ponto de contato que não pode ser deixado de lado.

Indiquei na seção anterior, mesmo sem ter desenvolvido de maneira suficientemente detalhada, a existência, em Schopenhauer, de uma teleologia éticosoteriológica, cujo telos seria a produção das condições materiais para a supressão e a negação da vontade no organismo humano (o desenvolvimento extraordinário e em certa medida "antinatural" do cérebro, do qual emerge sua capacidade superior para a reflexividade). Minha hipótese principal quanto a isso é que o surgimento dessas condições não é algo como um "acidente de percurso" no processo de manifestação da vontade no mundo. Trata-se de um episódio não apenas “previsto”, como intencionalmente visado, decorrente de um princípio de ordem teleológica que é metafisicamente ao menos tão originário quanto (senão mais originário que) o princípio que orienta as exteriorizações da vontade no sentido de sua constante afirmação e que produz cada fenômeno e cada estrutura orgânica em função de sua capacidade de promover o surgimento, a conservação e a expansão da vida. Isso faz com que tenhamos de encarar o problemático princípio da finalidade da natureza no pensamento de Schopenhauer como contendo duas ordens distintas e em grande medida contraditórias, e que podemos denominar, acompanhando a terminologia do próprio autor, ordem da natureza e ordem da salvação, num sentido análogo à contraposição discutida anteriormente entre reino da natureza e reino da graça. A essa contraposição se junta agora uma outra, que Schopenhauer, no espírito das reflexões que se encontram em Especulação transcendente, formula nos termos da oposição entre "fim da vontade individual" e "fim do destino":

Em realidade, o que dá a nossa vida seu caráter estranho e ambíguo é que nela se cruzam a todo momento dois fins fundamentais e diametralmente opostos: o fim da vontade individual, direcionado a uma felicidade quimérica, numa existência efêmera, onírica, ilusória [...]; e, por outro lado, o fim do destino, flagrantemente direcionado à destruição de nossa felicidade e assim à mortificação da nossa vontade e supressão da ilusão que nos prendeu às correntes deste mundo. (W II, § 49, 732)

\footnotetext{
${ }^{50}$ FREUD, Jenseits des Lustprinzips, 68.

${ }^{51}$ FREUD, Jenseits des Lustprinzips, 60.
} 
Ora, o que vemos nessas reflexões é uma luta entre duas tendências opostas: a afirmação e a negação da vontade. Ambas as tendências se originam da mesma fonte: a própria vontade que se afirma ou se nega. A ambas corresponde igualmente um princípio teleológico, o que faz com o que o mundo seja a via de instanciação daquelas duas ordens de finalidade distintas e contrárias. Essa perspectiva traduz o evidente monismo ontológico da vontade num dualismo de seus princípios teleológicos ${ }^{52}$. Mas o princípio de negação da vontade, diferentemente de sua afirmação, só pode se realizar num único tipo natural: o ser humano, que se encontra no topo da pirâmide da natureza. Por conseguinte, a vontade só pode negar-se a si mesma, no único ato de liberdade possível no mundo fenomênico, após ter percorrido toda a série de manifestações correspondentes aos seus graus inferiores de objetivação, das forças da massa planetária ao macaco.

O mais interessante de se notar nisso tudo é que, uma vez que penetramos nas camadas mais profundas das reflexões teleológicas e da soteriologia de Schopenhauer, percebemos que toda sua filosofia da natureza, com sua teleologia funcional (direcionada à produção e à expansão da vida), já se encontra, desde o início, atravessada e determinada pelo princípio da negação da vontade de vida. Que todo o desenvolvimento da série evolutiva dos graus de objetivação da vontade encontre no ser humano sua consumação, só se explica pelo fato de que é nele, unicamente, que a vontade se conhece a si mesma e, como resultado desse autoconhecimento, alcança sua redenção pela autonegação ${ }^{53}$. É por isso que o destino de cada um de nós é sermos sistematicamente confrontados com o sofrimento, a frustração e a infelicidade, para que ao fim e ao cabo, diante da morte, possamos dizer em alto e bom som: "Basta desse jogo". Assim, "só o humano esvazia de fato o copo da morte", pois a humanidade é "o único degrau no qual a vontade se nega e pode renunciar por completo à vida” (W II, § 49, 730).

Tanto em Freud quanto em Schopenhauer, portanto, há “algo” em nós que tende ao esvaziamento, à supressão da força vital, à eliminação da energia pulsional, à extirpação das moções volitivas. Em Freud, esse esvaziamento se dá no retorno ao inorgânico (ao mineral), que é destituído de energia pulsional. Dentro desse contexto, em que pese seu

\footnotetext{
${ }^{52}$ No parágrafo 161 do ensaio intitulado: Suplementos à doutrina da afirmação e da negação da vontade de vida, pertencente ao segundo volume dos Parerga, Schopenhauer concebe a oposição entre esses dois princípios mediante a contraposição dos termos Velle e Nolle: "A afirmação e a negação da vontade de vida é um mero Velle et Notte. - O sujeito de ambos os actus é um e o mesmo, e por conseguinte não será aniquilado como tal nem por um nem por outro ato. Seu Velle se apresenta neste mundo intuitivo, que justamente por isso é o fenômeno de sua coisa em si. - Contudo, do Nolle não conhecemos nenhum outro fenômeno a não ser o de sua aparição no indivíduo, que originalmente já pertence ao fenômeno do Velle: por isso vemos, enquanto o indivíduo existe, o Nolle constantemente em luta com o Velle" (P II, 338s.). Para uma interpretação da concepção schopenhaueriana da relação entre vida e morte focada neste aspecto da luta entre o Velle e o Nolle, cf. ALMEIDA, Eros e Tânatos: a vida, a morte, o desejo (capítulo III).

${ }^{53}$ Cf. W I, § 52, 315: "todo o mundo visível é apenas a objetivação, o espelho da vontade que a acompanha para seu autoconhecimento" e, com isso, "para a possibilidade de sua redenção."
} 
forte teor especulativo, sua teoria pode ainda ser compreendida no registro empírico: a pulsão de morte se desdobra e se realiza inteiramente no plano da natureza, emergindo naturalmente no organismo nascente e conduzindo esse organismo ao estado inorgânico. Em Schopenhauer, essa solução está excluída de antemão. O inorgânico, para o filósofo, de modo algum é destituído de energia volitiva. Pelo contrário, cada força que se manifesta na matéria morta (gravidade, solidez, magnetismo, eletricidade) representa um movimento da vontade que busca se afirmar. A interação entre essas forças em sua luta pela posse da matéria é o que produz seres cada vez mais complexos na série dos fenômenos naturais (W I, § 27, 173ss.). Por isso, o esvaziamento em Schopenhauer só pode se dar mediante um salto para além da ordem natural, para além da physis. Como dito, a negação da vontade é um ato de liberdade que realiza uma finalidade suprassensível, irredutível à dinâmica interna do organismo animal. Se a morte aparece aqui como uma finalidade, é apenas no sentido em que esse fenômeno de término da vida individual põe às claras, à consciência racional, o absurdo dos desejos e anseios aos quais o indivíduo se submete em seu percurso de vida. Essa consciência da radical falta de sentido que emerge do confronto com a morte funciona como deflagrador daquela tendência metafísico-moral latente em nós, daquele “algo" que anseia pelo não-anseio, que busca uma ruptura com a ordem natural da afirmação da vontade: a experiência da morte tem efeito catalisador, tornando possível a virada que direciona o indivíduo à redenção pela negação da vontade. Por isso a analogia com a graça cristã é tão importante e tão elucidativa.

\section{V}

Para concluir, gostaria de retomar brevemente e aprofundar a discussão de dois pontos da confrontação ensaiada aqui entre as posições de Freud e Schopenhauer: o significado da morte e a distinção entre ponto de vista empírico e ponto de vista metafísico.

Se temos em vista o que dissemos acima sobre o princípio do nirvana, podemos concluir que, assim como para Schopenhauer, não é a morte em si que configura, para Freud, o "fim” realmente visado pelos processos vitais: a morte é o 'significante', ao mesmo tempo 'existencial e biológico' (uso a expressão em licença poética) ao qual se adere o sentido de esvaziamento, de ausência de excitação (a "quietude do mundo inorgânico"). É esse esvaziamento pulsional, portanto, que configura o fim propriamente dito. Como só há pulsão onde há excitação, pode-se dizer que a pulsão possui uma tendência natural ao auto-aniquilamento: "A tensão que sobreveio, na substância anteriormente inanimada, procurou anular a si mesma; foi o primeiro impulso, o de retornar ao inanimado" 54 . Há,

\footnotetext{
${ }^{54}$ FREUD, Jenseits des Lustprinzips, 40 (grifo nosso). Sobre essa tendência do impulso à autodissolução, cf. ZENTNER, "Das Ziel alles Lebens ist der Tod”, 332.
} 
quanto a isso, duas diferenças fundamentais entre Schopenhauer e Freud que precisam ser sublinhadas: em primeiro lugar, para Schopenhauer, o inorgânico não satisfaz essa condição de esvaziamento, pois ele é ainda manifestação da vontade de vida. Nesse contexto, não haveria uma diferença substantiva relevante entre as excitações propriamente ditas no organismo e as reações químicas e físicas que os entes do mundo inorgânico sofrem, e a partir das quais eles "se comportam" de determinada maneira 55 .

Em segundo lugar, a hipótese freudiana de que todas as mudanças pelas quais o organismo passa, e mediante as quais ele se transforma e "evolui", são efeitos de influências externas, que perturbam sua tendência natural à conservação, se opõe à tese schopenhaueriana de que a vontade tende sempre, a partir de um princípio interno, à produção de formas cada vez mais elevadas de manifestação, até atingir seu ápice no ser humano ${ }^{56}$. Se há de fato algo como uma "pulsão de morte" em Schopenhauer (uma "vontade de nada"), ela só emerge visivelmente no ser humano, no ápice da pirâmide da natureza, após toda a série dos entes naturais ter chegado à sua consumação através de desenvolvimentos contínuos teleologicamente orientados. Ou seja, a vontade precisa perfazer um longo caminho antes de produzir as condições materiais necessárias para sua autonegação, e somente então, em casos muito raros, manifesta-se como anseio à supressão de si mesma, um anseio produzido pelo autoconhecimento.

Tendo isso em vista, a distinção entre os dois autores se revelaria, primeiramente, como uma distinção (de resto já vastamente reconhecida) entre o ponto de vista empírico de Freud (em que o inorgânico está 'vazio de vida', já que a vida é definida em sentido biológico) e o ponto de vista metafísico de Schopenhauer (em que o inorgânico está preenchido pela vontade de vida, já que a vida aqui é definida em sentido metafísico ${ }^{57}$; em segundo lugar, pelo fato de que, para Schopenhauer, a tendência empiricamente visível de toda a vida é alcançar a perfeição de suas formas orgânicas - é somente depois, com o surgimento do intelecto humano, que manifesta-se a "virada" dessa tendência contra si própria. Pode-se argumentar, é verdade, que de um ponto de vista teleológico mais profundo (daquilo que eu chamei de teleologia ético-soteriológica), todo o desenvolvimento das formas orgânicas até a perfeição do cérebro humano já estava direcionado a esse fim

\footnotetext{
${ }_{55}$ Com efeito, Schopenhauer sugere que aquilo que caracteriza essencialmente a vida (a responsividade a estímulos e a sensibilidade animal), deve poder ser gradualmente expandido à totalidade da natureza (como análogos seus, cada vez mais despotencializados), de modo que, entre a sensibilidade humana, a sensibilidade animal, a receptividade a estímulos dos vegetais, as reações químicas dos materiais e os efeitos físicos e mecânicos dos movimentos dos corpos, devemos reconhecer distinções apenas de grau. Sobre isso, cf. MATTIOLI, “Dem Willen zum Leben ist das Leben gewiß”, 206, e as referências ali indicadas.

${ }^{56}$ Freud recusa explicitamente essa ideia: “Certamente não se constata, no mundo das plantas e dos animais, um impulso universal rumo ao desenvolvimento mais elevado, embora permaneça indiscutível que há uma tal direção no desenvolvimento.” (Jenseits des Lustprinzips, 43)

57 Discuto esse conceito metafísico de vida e sua relação com a teleologia no já mencionado artigo “Dem Willen zum Leben ist das Leben gewiß: vida e finalidade em Schopenhauer".
} 
soteriológico principal que é a redenção pela negação da vontade, e que a vida só produziu todas essas formas animais, na série evolutiva da natureza, porque essas formas animais eram condições necessárias para o surgimento e a conservação de um ente capaz de negar a vontade. Desse ponto de vista, o impulso à negação da vida seria metafisicamente primitivo com relação ao impulso à afirmação da vida. O problema, nesse caso, se tentamos estabelecer um paralelo com Freud, é que esse impulso à negação da vida não pode ser deduzido dos fenômenos biológicos naturais, como quer a tese freudiana em torno da compulsão à repetição e da tendência regressiva dos impulsos (a partir da observação dos instintos migratórios dos animais e da teoria da recapitulação de Haeckel, por exemplo) que fundamenta a hipótese das pulsões de morte. Em Schopenhauer, a negação da vontade só pode ser constatada em certos comportamentos humanos (em especial na vida dos santos e ascetas), para então ser traduzida em tese metafísica.

Não me parece promissor sugerir aqui que, para Schopenhauer, a morte biológica representaria, em qualquer sentido, a manifestação dessa tendência à negação da vida no interior do mundo natural. E isso por dois motivos: o primeiro deles é que a morte biológica atinge apenas o indivíduo, fenômeno da vontade de vida, mas não a vida da espécie (cf. W I, § 54; W II, §§ 41-42; P I, 232), que permanece como vida imortal subjacente a todo nascimento e perecimento dos seres individuais - nascimento e morte sendo apenas momentos do mesmo ciclo vital da espécie ${ }^{58}$; o segundo motivo é que, aos olhos de Schopenhauer, a morte de alguns indivíduos no mundo natural se dá, em grande parte, justamente como meio para a afirmação da vontade de vida por parte de outros indivíduos, que destroem os primeiros, seja para servir-se deles como alimento, seja para eliminar os obstáculos que eles representam para sua autoafirmação e autoexpansão. É justamente mediante a morte do outro, resultado da luta pela matéria, que a vontade de vida pode ascender a formas mais elevadas.

Talvez este último argumento não seja tão decisivo quanto o primeiro, pois o que importa fundamentalmente a Freud é a morte natural, resultante de causas internas ao próprio organismo (imanentes ao seu desenvolvimento) e não a morte por causas externas. Contudo, na metafísica da natureza de Schopenhauer, essa distinção não é tão relevante: "o que é exterior a mim e o que é interior em mim, enquanto algo espacial, reside apenas no fenômeno” (W II, § 41, 580). Assim, se a morte do animal que foi devorado por outro pode ser vista, do ponto de vista empírico, como 'morte por causa externa', do ponto de vista metafísico (da unidade da vontade) trata-se ainda de um ato de autocanibalismo, da vontade que crava os dentes na própria carne. Visto de outro ângulo: se temos, na

\footnotetext{
${ }^{58}$ Nesse ponto em específico, Schopenhauer me parece mais próximo do biólogo Weismann, citado e criticado por Freud, que defende algo como uma 'prioridade ontológica da vida', compreendendo a morte como mero resultado de uma combinação de acasos no desenvolvimento da vida entre os seres pluricelulares (cf. Jenseits des Lustprinzips, 49s.). Sobre isso, cf. também os esclarecedores comentários de GIACOIA JÚNIOR, Ontologia e metapsicologia: considerações sobre o dualismo pulsional, p. 128ss.
} 
alimentação predatória, uma matéria antes dominada pela força vital da vontade do animal vivo (da presa), que passa agora, por assimilação, a ser dominada pela força vital da vontade do predador que o devorou; da mesma forma temos, no caso da assim chamada morte natural, uma matéria antes dominada pela força vital da vontade do animal vivo, que passa então a ser dominada pelas forças químicas e físicas presentes na matéria orgânica, e contra as quais a força vital lutava constantemente para conservar a forma do organismo e impedir a desagregação de suas partes. Em ambos os casos, são as forças naturais (forças físicas e químicas, força vital, espécies vegetais e animais, caracteres humanos inteligíveis - todos correspondentes às ideias) que lutam pela posse da matéria, essa matéria que é uma e a mesma em todos os fenômenos, pois todos os fenômenos são expressão de uma e mesma vontade.

Para encerrar, portanto, podemos retomar, à luz dessa luta constante pela matéria, na qual a vontade crava os dentes na própria carne, o ensinamento mais importante da metafísica schopenhaueriana: para além da individualidade dos caracteres humanos, o destino fundamental da vida que os atravessa é o mesmo; e o "Espírito do mundo" assim fala ao homem: "Deveria eu lhe dizer que o valor da vida consiste justamente em ensiná-lo a não querer?! Para esta mais alta consagração, a própria vida deve prepará-lo primeiro” ( $\mathrm{P}$ II, XIV, § 172, 348).

\section{Referências}

ALMEIDA, Rogério Miranda de. Nietzsche e Freud: eterno retorno e compulsão à repetição. São Paulo: Edições Loyola, 2005.

AlMEIDA, Rogério Miranda de. Eros e Tânatos: a vida, a morte, o desejo. São Paulo: Edições Loyola, 2007.

ANTONIASSI, Ednilson Bernardo. A noção de palingenesia na filosofia de Schopenhauer: uma contribuição para os debates sobre o processo de negação da vontade. In: Debona, V.; Decock, D. (Eds.). Schopenhauer: A filosofia e o filosofar [recurso eletrônico]. Porto alegre: Editora Fi, 2018.

ATZERT, Stephan. Zwei Aufsätze über Leben und Tod: Sigmund Freuds Jenseits des Lustprinzips und Arthur Schopenhauers Transscendente Spekulation über die anscheinende Absichtlichkeit im Schicksal des Einzelnen. Schopenhauer Jahrbuch, v. 86, p. 179-194, 2005.

BASSOLI, Selma. A negação da Vontade como um efeito da Graça: a redenção na concepção de Schopenhauer. Tese (Doutorado) - Faculdade de Filosofia, Letras e Ciências Humanas. Universidade de São Paulo: São Paulo, 2015. 
DEBONA, Vilmar. Um caráter abissal - a metafísica schopenhaueriana da Vontade como caracterologia. Revista Voluntas: Estudos sobre Schopenhauer, v. 4, n. 1, p. 33-65, 1 semestre de 2013. Disponível em: https://periodicos.ufsm.br/voluntas/article/view/33988. Acesso em: 15/06/2020.

DEBONA, Vilmar. A propósito da noção de "caráter": as presenças de Kant e Schelling na tese de doutorado de Schopenhauer. Cadernos de Filosofia Alemã, São Paulo, v. 20, n. 2, p. 67-85, jul./dez. $2015 . \quad$ Disponível em: http://www.revistas.usp.br/filosofiaalema/article/view/111024. Acesso em: 15/06/2020.

DEBONA, Vilmar. Pessimismo e eudemonologia: Schopenhauer entre pessimismo metafísico e pessimismo pragmático. Kriterion, Belo Horizonte, n. 135, p. 781-802, dez./2016. Disponível em: <https://www.scielo.br/pdf/kr/v57n135/0100-512X-kr-57-1350781.pdf>. Acesso em: 15/06/2020.

DEBONA, Vilmar. Destino e fatalismo em Schopenhauer. Sofia, Vitória, v. 7, n. 2, p. 82-93, jul./dez. 2018. Disponível em: http://www.periodicos.ufes.br/sofia/article/view/20773/16387. Acesso em: 15/06/2020.

DEBONA, Vilmar. A outra face do pessimismo: caráter, ação e sabedoria de vida em Schopenhauer. São Paulo: Edições Loyola, 2020.

FONSECA, Eduardo Ribeiro da. Psiquismo e vida: sobre a noção de Trieb nas obras de Freud, Schopenhauer e Nietzsche. Curitiba: Ed. da UFPR, 2012.

FONSECA, Eduardo Ribeiro da. Sexualidade e morte em Schopenhauer: o abismo insondável da vontade. In: Carvalho, R.; Costa, G.; Mota, T. (Orgs) Nietzsche Schopenhauer: metafísica e significação moral do mundo. Fortaleza: EdUECE, 2014.

FREUD, Sigmund. Das Unbewusste. In: FREUD, Sigmund. Gesammelte Werke. Bd. X. London: Imago Publishing, 1946.

FREUD, Sigmund. Eine Schwierigkeit der Psychoanalyse. In: FREUD, Sigmund. Gesammelte Werke. Bd. XII. Frankfurt am Main: Fischer Verlag, 1966.

FREUD, Sigmund. Jenseits des Lustprinzips. In: FREUD, Sigmund. Gesammelte Werke. Bd. XIII. Frankfurt am Main: Fischer Verlag, 1967.

FREUD, Sigmund. $O$ inconsciente. In: Obras completas, volume 12. Introdução ao narcisismo, Ensaios de metapsicologia e outros textos (1914-1916). Tradução de Paulo César de Souza. São Paulo: Companhia das letras, 2010.

FREUD, Sigmund. Uma dificuldade da psicanálise. In: Obras completas, volume 14. História de uma neurose infantil (“O homem dos lobos”), Além do princípio do prazer e outros textos (1917-1920). Tradução de Paulo César de Souza. São Paulo: Companhia das letras, 2010. 
FREUD, Sigmund. Além do princípio do prazer. In: FREUD, Sigmund. Obras completas, volume 14. História de uma neurose infantil ("O homem dos lobos”), Além do princípio do prazer e outros textos (1917-1920). Tradução de Paulo César de Souza. São Paulo: Companhia das letras, 2010.

GARDNER, S. Schopenhauer, Will, and the Unconscious. In: Janaway, C. (Org.) The Cambridge Companion to Schopenhauer. Cambridge: Cambridge University Press, 1999.

GERMER, Guilherme Marconi. Apresentação à tradução de "O objetivo de toda a vida é a morte” - Schopenhauer e o instinto de morte de Freud, de Marcel Zentner. Voluntas: Revista Internacional de Filosofia, Santa Maria, v. 9, n. 2, p. 151-157, jul-dez. 2018. Disponível em: https://periodicos.ufsm.br/voluntas/article/view/35580/pdf. Acesso em: 15/06/2020.

GERMER, Guilherme Marconi. A concepção de morte em Schopenhauer. In: Debona, V.; Decock, D. (Eds.). Schopenhauer: A filosofia e o filosofar [recurso eletrônico]. Porto alegre: Editora Fi, 2018.

GIACOIA JÚNIOR, Oswaldo. Ontologia e metapsicologia: considerações sobre o dualismo pulsional. Ideias, Campinas, v. 3, n. 1, p. 123-143, 1. semestre 2012. Disponível em: $\quad$ https://periodicos.sbu.unicamp.br/ojs/index.php/ideias/article/view/8649366/15921. Acesso em: 17/06/2020.

GÖDDE, Günter. Traditionslinien des „Unbewussten“. Schopenhauer - Nietzsche - Freud. Gießen: Psychosozial-Verlag, 2009.

KOßLER, Matthias. „Das Leben ist nur ein Spiegel“ - Schopenhauers kritischer Lebensbegriff. ethic@, Florianópolis, v. 11, n. 2, p. 1-15, julho de 2012. Disponível em: https://periodicos.ufsc.br/index.php/ethic/article/view/1677-2954.2012v11nesp1p1/22990.

Acesso em 15/06/2020.

MALTER, Rudolf. Schopenhauers Transzendentalismus. Midwest Studies in Philosophy, v. 8, n. 1, p. 433-455, 1983.

MALTER, Rudolf. Der eine Gedanke. Hinführung zur Philosophie Arthur Schopenhauers. 2. Auflage. Darmstadt: Wissenschaftliche Buchgesellschaft, 2010.

MATTIOLI, William. O paradoxo das causas finais: Schopenhauer leitor da "Crítica do juízo teleológico”. Revista de Filosofia Aurora, Curitiba, v. 30, n. 49, p. 205-235, jan./abr. 2018. Disponível em: https://periodicos.pucpr.br/index.php/aurora/article/view/23446/22715. Acesso em: 15/06/2020.

MATTIOLI, William. “Dem Willen zum Leben ist das Leben gewiß”: vida e finalidade em Schopenhauer. Sofia, Vitória, v. 7, n. 2, p. 201-225, jul./dez. 2018. Disponível em: https://periodicos.ufes.br/sofia/article/view/21276/16397. Acesso em: 15/06/2010. 
SCHOPENHAUER, Arthur. Sämtliche Werke. Hrsg. v. Paul Deussen. München: Piper Verlag, 1911-1926. (Werke auf CD-ROM: Schopenhauer im Kontext).

SCHOPENHAUER, Arthur. O mundo como vontade e como representação. Trad. Jair Barboza. São Paulo: Editora Unesp, 2005. Tomo I.

SCHOPENHAUER, Arthur. $O$ mundo como vontade e como representação. Trad. Jair Barboza. São Paulo: Editora Unesp, 2015. Tomo II.

SCHOPENHAUER, Arthur. Sobre a ética. Organização e tradução Flamarion C. Ramos. São Paulo: Hedra, 2012.

SILVA, Luan Corrêa da. Metafísica prática em Schopenhauer. Tese (Doutorado) - Centro de Filosofia e Ciências Humanas. Programa de Pós-Graduação em Filosofia. Universidade Federal de Santa Catarina: Florianópolis, 2017.

SORIA, Ana Carolina Soliva. Schopenhauer em Além do princípio do prazer: reflexões sobre a relação entre metafísica e metapsicologia. In: Correia, A.; Debona, V.; Tassinari, R. (Orgs) Hegel e Schopenhauer. São Paulo: ANPOF, 2017. (Coleção XVII Encontro ANPOF).

ZENTNER, Marcel. „Das Ziel alles Lebens ist der Tod“. Schopenhauer und Freuds Todestrieb. Archiv für Geschichte der Philosophie, v. 75, p. 319-339, 1993. 